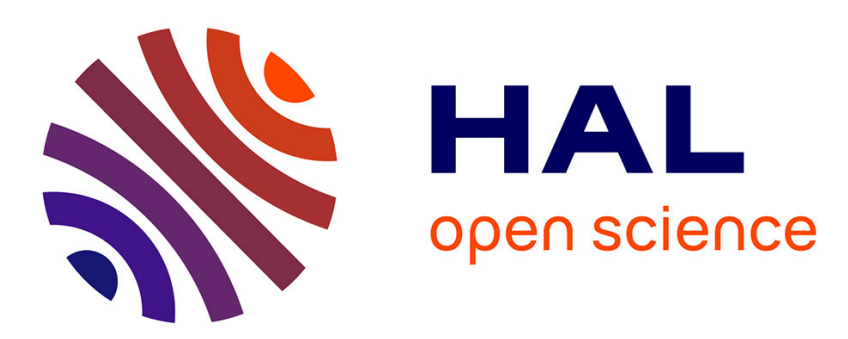

\title{
MORPHOLOGICAL SPLIT ERGATIVE ALIGNMENT AND SYNTACTIC NOMINATIVE-ACCUSATIVE ALIGNMENT IN PESH
}

Claudine Chamoreau

\section{- To cite this version:}

Claudine Chamoreau. MORPHOLOGICAL SPLIT ERGATIVE ALIGNMENT AND SYNTACTIC NOMINATIVE-ACCUSATIVE ALIGNMENT IN PESH. International Journal of American Linguistics, 2021, 87 (4), pp.501-537. halshs-03112558v1

HAL Id: halshs-03112558

https://shs.hal.science/halshs-03112558v1

Submitted on 16 Jan 2021 (v1), last revised 29 Oct 2021 (v2)

HAL is a multi-disciplinary open access archive for the deposit and dissemination of scientific research documents, whether they are published or not. The documents may come from teaching and research institutions in France or abroad, or from public or private research centers.
L'archive ouverte pluridisciplinaire HAL, est destinée au dépôt et à la diffusion de documents scientifiques de niveau recherche, publiés ou non, émanant des établissements d'enseignement et de recherche français ou étrangers, des laboratoires publics ou privés. 
Chamoreau, C. forthcoming. Morphological split ergative alignment and syntactic nominative-accusative alignment in Pesh. International Journal of American Linguistics.

\author{
MORPHOLOGICAL SPLIT ERGATIVE ALIGNMENT AND \\ SYNTACTIC NOMINATIVE-ACCUSATIVE ALIGNMENT IN PESH \\ Claudine Chamoreau \\ CNRS (CEMCA/SEDYL)
}

\begin{abstract}
Pesh (Chibchan, Honduras) has until now been described as having a morphological nominative-accusative alignment. This paper argues that Pesh displays a bi-level split ergative pattern for morphological alignment. On the first level of the system, Pesh features a split alignment that is conditioned by the way the arguments are expressed. It has a nominativeaccusative alignment for the obligatory indexing of arguments on the verb, and three systems of alignment for flagging case. The distribution of these three systems shapes the second level where ergative-absolutive, tripartite, and nominative-accusative are seen depending on the types of clause and the varieties spoken. On the other hand, Pesh shows a syntactic nominative-accusative alignment. Cross-clausal behaviors in two constructions show a subject/agent pivot. This is seen in the possibility of deletion of the $\mathrm{S}$ or the $\mathrm{A}$ in the second conjoined clause and the control of coreference with core arguments in a purpose clause.
\end{abstract}

[KEYWORDS: Chibchan, alignment, morphological split ergative, tripartite, syntactic nominativeaccusative]

\title{
1 Introduction $^{1}$
}

This paper deals with alignment in Pesh (Pech, Paya, ISO 639-3: [pay]), a language spoken in Honduras, classified as an outlier within the Chibchan family: it is the only language that does not belong to Core Chibchan (Constenla 2012). There is little information on Pesh in the literature. An overview dating from 1928 contains a list of Pesh words translated into Spanish (Conzemius 1928). More recently, a grammatical sketch was published by Holt (1999), based on data collected with questionnaires in some villages speaking the dialect of Culmi in 1974-75. In this sketch, Holt (1999:33-34) claims that Pesh has a morphological nominative-accusative

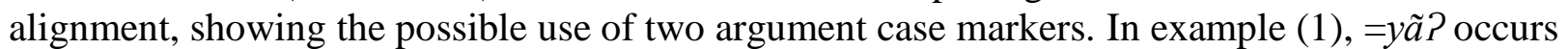
with arwấ 'man', while =ra occurs with $u$ '? 'jaguar'. 2

\footnotetext{
${ }^{1}$ I wish to thank Enrique Palancar, Roberto Zavala Maldonado and Stavros Skopeteas for their detailed and insightful comments on a previous version of my manuscript and to Timothy Feist for proof-reading the English language. I am also grateful to the associate Editors for IJAL and to two anonymous reviewers for their comments and suggestions. They all helped me understand some of the phenomena in the dynamics I propose.

2 In Holt's transcription, the accents indicate types of tone, and the tilde indicates nasalization. I follow his transcription and his translation, but I use an equals sign in place of a hyphen for cases, the topic and the focus markers, and subordinators, as I consider them to be clitics. The glosses are mine. In my transcription, I use the International Phonetic Alphabet and I do not indicate tone since the production of tones is very irregular and generally our collaborators do not produce them. Before the example, I indicate the variety that it comes from. Abbreviations are as follows: 1 first person; 2 second person; 3 third person; ABS absolutive; ACC accusative; AG agent; APPL.P applicative for patient; APPL.R applicative for recipient; ART article; COM comitative; COND conditional;
} 
Culmi

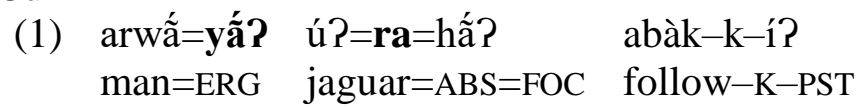

'The man followed the jaguar.' (Holt 1999:34)

In (1), the case marker $=y \tilde{a} P$ is used with the A argument and the case marker $=r a$ with the $\mathrm{O}$ argument. ${ }^{3}$ Holt gives less than ten examples of clauses with argument case markers. However, two examples contradict his nominative-accusative analysis. To explain the use of $=r a$ with the S tas 'I', in example (2), he noted that "subjects of if-clauses are usually marked by the objective case-suffix" (Holt 1999:71). ${ }^{4}$

Culmi
(2) tàs=rấ?
nàst-a-rì? =mā?
šùš̀ $=\mathrm{ma}$
tà?-ẽ̀?-íš $(\mathrm{k})-\mathrm{t}-\tilde{1}$ ?
PRO1=ABS:FOC jump-S1SG-PST=if
dog=TOP
S1SG-bite-COND-NEG-PST
'If I had jumped, the dog would not have bitten me.' (Holt 1999:71)

Moreover, he advanced the hypothesis that the use of =ra in the context of if-clauses is related to the active verb, contrasting the example in (2), with the active verb nàst 'jump', with the example in (3), containing the stative verb š்̃ 2 'see' in which the ergative case marker $=y \tilde{a} ?$ is used.

Culmi
(3)
tàs=yã́? šà̀?-a-rì?=mã? $\quad$ sukùh-ǐšk-(a)-ri? $\quad$ à=ma
PRO1=ERG see-S1SG-PST=if grab-COND-(1s)-PST DEM.DIST=TOP
'If I had seen that, I would have grabbed it.' (Holt 1999:71)

Nevertheless, the example given in (4) offers another context where the case marker $=r a$ occurs with an S.

Culmi

(4)
pèš-ákwa=rah músti=ri=rás
people-other=ABS many=COP:S3SG:PST=REAS
'because there were so many Latinos.' (Holt 1999:79)

\begin{abstract}
COP copula; C.Q content question; DEM.DIST distal demonstrative; DEM.MED medial demonstrative; DEM.PROX proximal demonstrative; DES desiderative; DUR durative; EMPH emphatic; ERG ergative; EXCL exclusive; FOC focus; FUT future; HUM human; INCL inclusive; INDF indefinite; INS instrumental; INTR intransitive; K unknown suffix; LOC locative; MAN manner; MC matrix clause; NEG negation; NMLZ nominalizer; NOM nominative; NP noun phrase; O object; PFV perfective; PL plural; POSS possessive; PP postpositional phrase; P.Q polar question, PRO pronoun; PST past; PURP purpose; RC relative clause; REAS reason subordinator; REC recent; REFL reflexive; REP reportative; $\mathrm{S}$ subject; SG singular; SIM similative; TEMP temporal; TOP topic; TR transitive; V verb; W vowel.

${ }^{3}$ In this paper, I use Dixon's distinctions of A (transitive subject), S (intransitive subject) and O (transitive object) that refer to the formal encoding of arguments (Dixon 1979).

4 The expression "objective case-suffix" in Holt's terminology corresponds to absolutive case marker in ergative-absolutive alignment. The case marker $=y \tilde{a}$ ? is called "nominative case" by Holt (Holt 1999:33).
\end{abstract}


In the clause in (4), the argument is the $\mathrm{S}$ of the non-verbal predicate músti 'many'; this is not an active verb nor an if-clause, despite the fact that Holt claimed these are the two contexts in which the $=r a$ marker may be used with subjects (Holt 1999:71). In Holt's data, the examples in (2) and (4) are the only examples of the use of the $=r a$ (or =rah) marker with a NP functioning as S in an intransitive clause. In the absence of other examples and further explanations, it might be possible to analyze the $=r a$ (or $=r a h)$ markers as instances of absolutive marking, since $\mathrm{S}$ in these two intransitive clauses is marked like $\mathrm{O}$, as in (1). For Holt, the difficulty in determining the alignment in Pesh could be related to the brevity of his description and the lack of a comprehensive corpus. In a more general way, the difficulty in determining the alignment in Pesh is a consequence of the complexity of the phenomenon as it is conditioned by various factors.

In this paper, I argue that Pesh shows a bi-level split ergative pattern for morphological alignment, this split being conditioned by the way the arguments are expressed. The first level of the system reveals a tension between the two systems of marking in the language- - head marking (i.e., the indexing of arguments on the verb) vs. dependent marking (i.e., the flagging of case). In all the varieties of Pesh, the indexing of arguments on the verb shows nominative-accusative alignment, while the flagging of case follows three different systems of alignment. The distribution of these three patterns shapes the second level of the system. In all Pesh varieties, interrogative content clauses follow an ergative-absolutive pattern. Case marking is obligatory in this type of clause. In independent and subordinate clauses, overt case marking of arguments is not obligatory. Pesh has an ergative-absolutive pattern for flagging overt noun phrase arguments in the variety spoken in Carbón, but in the variety spoken in Culmi, in the same contexts, it shows a tripartite pattern. In all the varieties, in relative clauses the marking is obligatory and Pesh has a nominative-accusative pattern. Thus, at the second level, ergative-absolutive, tripartite, and nominative-accusative are represented depending on the type of clause and the variety spoken.

Syntactically Pesh shows a nominative-accusative alignment. Cross-clausal behaviors in two constructions show that the target of a syntactic operation is always the S/A, or, in other words, Pesh has an S/A pivot. This is shown by (i) the possibility of deletion of the $\mathrm{S}$ or the $\mathrm{A}$ in the second clause when two clauses are conjoined; and (ii) the control of coreference with core arguments in a purpose clause.

In the next section, I introduce some of the basic features of Pesh. In Section 3, I explain the characteristics of the nominative-accusative pattern for verb-agreement affixes. In Section 4, I describe the mandatory ergative-absolutive pattern in interrogative content clauses and, in Section 5, I explain the behavior of both patterns in independent clauses and subordinate clauses in the varieties of Pesh. In Section 6, I show the characteristics of the obligatory nominativeaccusative pattern in relative clauses. In Section 7, I argue that Pesh has a unified syntactic nominative-accusative alignment. I conclude in Section 8 with a summary of the proposal showing the relevance of this topic for Chibchan languages.

\section{Basic features in Pesh}

Pesh is an endangered language as it has roughly 500 speakers, of whom $80 \%$ are over 60 years old. Map 1 shows the area where Pesh is spoken. Pesh has three varieties. The central Carbón variety is spoken by 250 speakers (half of the speakers). Carbón is a kind of conservative variety as it is used as an everyday language of communication by almost 160 people in two 
villages and retains some pragmatic morphemes absent from the other varieties such as the mirative marker or the inferential evidential marker. The southern Culmi variety is spoken by almost half of the speakers, but $93 \%$ of them are over 60 years old, and this variety includes the northern villages of Moradel and Silin. The eastern Las Marias variety is only spoken by five semi-speakers and is influenced by the Miskitu language (Misumalpan family). I do not include this last dialect in this study, due to high contact with Miskitu, and to unreliable data. ${ }^{5}$

FIGURE 1

PESH in HONDURAS

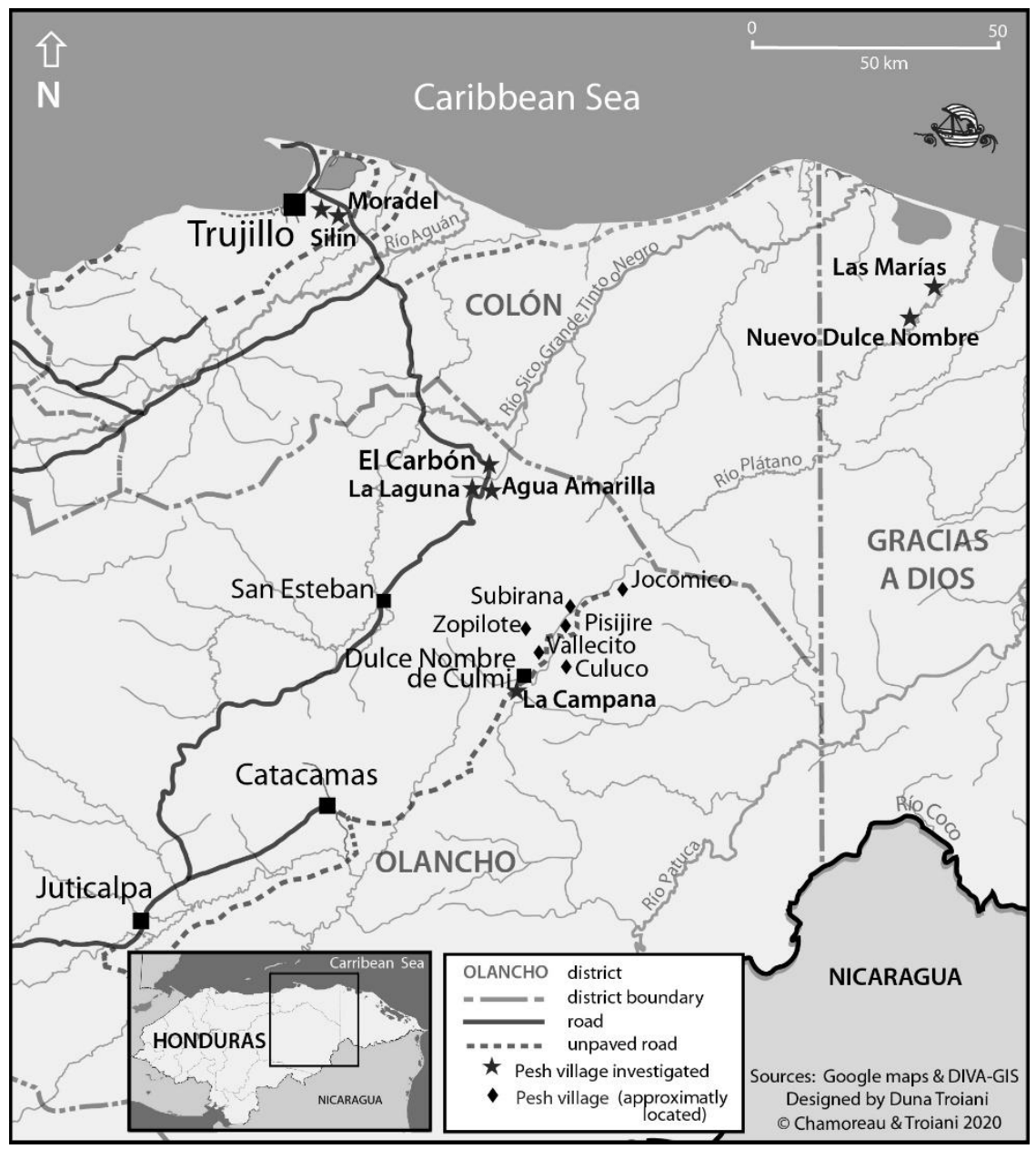

${ }^{5}$ The data presented in this paper were collected as part of the Major Documentation Project MDP0276, "A CrossVarietal Documentation and Description of Pesh, a Chibchan Language of Honduras" (https://elar.soas.ac.uk/Collection/MPI1050997) funded by HRELP (the Hans Rausing Endangered Languages Programme). I am greatly indebted to HRELP for their financial support. The support of the Centre National de la Recherche Scientifique (CNRS), the Centre d'Etudes Mexicaines et Centraméricaines (CEMCA), the Institut National des Langues et Civilisations Orientales (INALCO), the Laboratory Structure et Dynamique des Langues (SeDyL), and the Laboratory of Excellence-Empirical Foundations of Linguistics (LABEX-EFL) has also been important. I extend my deepest thanks to all my consultants: this research would not have been possible without the support of Juana Hernández Duarte, Ángel Martínez Torres, Hernán Martínez Escobar, Danilo Lugo Mendoza, Nimer López Garcia, and all our Pesh hosts. 
Pesh has the main features associated with verb-final languages. The respective roles of noun phrases preceding the verb are indicated by their position, and usually no case marking of core arguments is used, as shown in the intransitive clause in (5) where the $S$ occurs before the verb.

Culmi

(5)

$$
\begin{aligned}
& \begin{array}{l}
\text { ã } \\
\text { uttrã te?-nã-er-ri }
\end{array} \\
& \text { DEM.DIST fish come-go-S3PL-PST } \\
& \text { 'These fishes came and went away.' }\{\text { txt }\}^{6}
\end{aligned}
$$

In the monotransitive clause in (6), the A arwã 'man' precedes the $\mathrm{O}$ sina 'winkle'.

\section{Culmi}

$$
\begin{array}{lll}
\text { A } & \text { Opatient } & \mathrm{V} \\
\text { arwã } & \text { sija } & \text { nẽ- } \varnothing-\text { ũwe?-er-teP-k-er-wa } \\
\text { man winkle } & \text { go-O3SG-collect-S3PL-come-K-S3PL-PFV } \\
\text { 'Men went and came to collect winkles.' }\{\text { txt }\}
\end{array}
$$

In ditransitive clauses, as in (7), the A precedes the $\mathrm{O}$ that represents the theme, which in turn occurs before the $\mathrm{O}$ that indicates the recipient.

Culmi

\begin{tabular}{llll} 
A & O$_{\text {THEME }}$ & \multicolumn{1}{c}{ ORECIPIENT $_{\text {R }}$} & $\mathrm{V}$ \\
ta-tus & tas & ta-suwa & $\emptyset$-wi $\int-\mathrm{k}-\mathrm{er}-\mathrm{i}$ \\
POSS1-father & PRO1 & POSS1-grandmother & O3 SG-give.O3-K-S3PL-PST \\
'My parents entrusted me to my grandmother.'
\end{tabular}

Postpositional phrases (PPs) usually appear before the verb and are marked by an enclitic such as the comitative $=y o$ or the locative $=y \tilde{a}$, as shown in (8).

Culmi

$$
\begin{aligned}
& \text { LOC COM } \quad \mathrm{V} \\
& \text { taha=yã ta-arki=yo as nã-a-i=wĩ } \\
& \text { path }=\text { LOC } \quad \text { POSS1-man's.brother }=\mathrm{COM} \text { one go-S1SG-PST=long.ago } \\
& \text { 'Long ago, I went with one of my brothers on the path.' }\{\text { txt }\}
\end{aligned}
$$

The properties of a NP are those typically associated with head-final characteristics. The possessor occurs before the possessee, as in (9) where katfara-ha 'stream' is preposed to a-tah 'foot' which is obligatorily marked by a possessive marker. The numeral and the article are always postposed, as in (8).

\footnotetext{
${ }^{6}\{$ txt $\}$ means that the example comes from the corpus. For examples that come from elicited data, nothing is indicated.
} 
Carbón

Possessor-Possessee

(9)

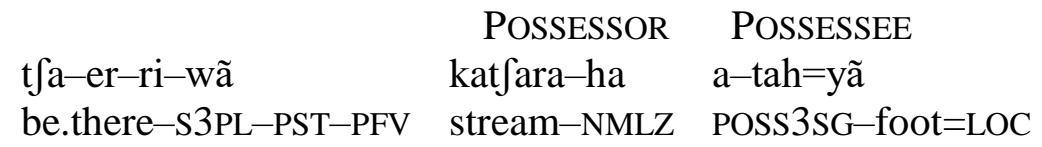

'Once, they were at the foot of a stream of water.' $\quad\{\mathrm{txt}\}$

Pesh is a case-marking language with the seven case enclitics listed in (10).

$\begin{array}{ll}\text { Phrasal case enclitics } \\ =y a & \text { Ergative } \\ =m a & \text { Nominative (only in relative clauses) } \\ =r a /=r o & \text { Accusative or Absolutive (depending on clause type, =ra, in the Culmi } \\ & \text { variety and =ro, in the Carbón dialect) } \\ =y a & \text { Locative } \\ =y o & \text { Comitative/instrumental } \\ =k a n /=k e n & \text { Similative (=kan, in the Culmi variety and =ken, in the Carbón dialect) } \\ =r i & \text { Temporal/manner }\end{array}$

This list shows the case markers found in Pesh in different constructions and varieties. For arguments, ergative and absolutive case markers are used in interrogative content clauses in all the varieties and in independent clauses and subordinate clauses in the Carbón variety. Ergative and accusative case markers are used in the Culmi variety in independent clauses and subordinate clauses and nominative and accusative case markers in relative clauses in all the varieties. The case markers found in postpositional phrases are used in all the varieties. Casemarking enclitics are phrase final, as shown in (11).

\section{Carbón}

$$
\begin{aligned}
& \text { a. pa-ta-wãta } \quad \text { pe=ro } \quad \text { te?- } \varnothing-\text { wa } \\
& \text { INCL-POSS1-shaman only=ABS come-S3SG-PFV } \\
& \text { 'Only our shaman came.' }\{\text { txt }\}
\end{aligned}
$$

$$
\begin{array}{lll}
\text { b. witfã } & \text { a-kwãsa=ro } & \text { a-r-kapar-k-er-wa } \\
\text { fish } & \text { POSS3SG-spirit=ABS } & \text { O3SG-APPL.P-thank-K-S3PL-PFV }
\end{array}
$$

'They thanked the spirit of the fish.' [and no other spirit] $\quad$ txt $\}$

In (11a) the noun phrase that functions as $\mathrm{S}$, pa-ta-wãta pe 'only our shaman', is marked with the absolutive case, like the $\mathrm{O}$ witfã $a-k w a \tilde{s} a$ 'the spirit of the fish', in (11b).

In both independent and subordinate clauses, Pesh shows a typologically uncommon pattern where overt case marking of arguments is not obligatory, but instead is variable (known in the literature as a "fluid system" Dixon 1994; "fluid differential case marking" de Hoop and Malchukov 2007 or "optional ergative marking" McGregor and Verstraete 2010). The use of case markers for arguments is triggered by the information structure. ${ }^{7}$ A change in constituent

\footnotetext{
${ }^{7}$ Research on the correlation between the presence of case marking and information structure is ongoing. First advances of what is shown in this paper have been previously introduced (Chamoreau 2018). A precise description
} 
order, showing the focalization of the constituents, triggers the use of case markers, as in (12) where the $\mathrm{O}$ tẽytawa 'friend' occupies the extreme left position of the clause when it functions as topic, and is marked by the topic marker =ma. The A ye? 'small' follows the $\mathrm{O}$ and takes the ergative marker.

Carbón

\begin{tabular}{|c|c|c|}
\hline [OpATIENT & $\begin{array}{l}\text { A } \\
\text { ye?=ya }\end{array}$ & $\begin{array}{l}\mathrm{v}] \\
\text { ka-puru-pi }\{-\mathrm{k}\end{array}$ \\
\hline -friend & small $=$ ERG & $\mathrm{Ct}-\mathrm{K}-\mathrm{S} 3 \mathrm{PL}-\mathrm{FUT}=$ \\
\hline
\end{tabular}

ka-puru-pif-k-er-wa

O3PL-look.for-protect-K-S3PL-PFV

'When the boys should help their friends, they help them.' $\{\mathrm{txt}\}$

In ditransitive verbs, Pesh exhibits a neutral alignment for flagging the $\mathrm{O}$ as the case marker $=r a$ is used with the theme, as in (13), or with the recipient, as in (14).

\section{Carbón}

$\begin{array}{lll}\text { A } & \text { O }_{\text {THEME }} & \mathrm{V} \\ \text { pe } \int-\text { kaki=ma } & \text { kaya-S=ro } & \text { ka-Pi }- \text {-k- }- \text { - } \mathrm{pi} \\ \text { POSS3PL-mother=TOP } & \text { story-INDF.ART=ABS } & \text { O3PL-tell-K-S3SG-FUT }\end{array}$

$$
\begin{aligned}
& \text { O }_{\text {RECIPIENT }} \\
& \text { a-ye?-ler } \\
& \text { POSS3SG-small-PL }
\end{aligned}
$$

'This is a story that the mother will tell to her children.' $\quad$ txt $\}$

\section{Carbón}

(14)

$$
\begin{aligned}
& \text { ORECIPIENT } \quad \mathrm{V} \quad \mathrm{A} \\
& \text { ã } \quad \text { arwã=ro } \varnothing-k a P-\varnothing-i=n a \quad \text { wi ã } a-k a k i=y a \\
& \text { DEM.DIST man=ABS O3SG-make-S3SG-PST=REP fish POSS3SG-mother }=\text { ERG } \\
& \text { 'They said that it was this man to whom the mother of the fishes did it.' }\{\mathrm{txt}\}
\end{aligned}
$$

This is the same absolutive case marker =ra used with the patient of a monotransitive verb, as in (11b).

In a few examples, no change in constituent order occurs, so the use of a case marker could be characterized as "uneconomical" and unnecessary. It reveals a modification in the information structure, as in (15).

of the correlation between each type of argument and the type of focus will be demonstrated later in a forthcoming publication. 
Carbón

(15) A

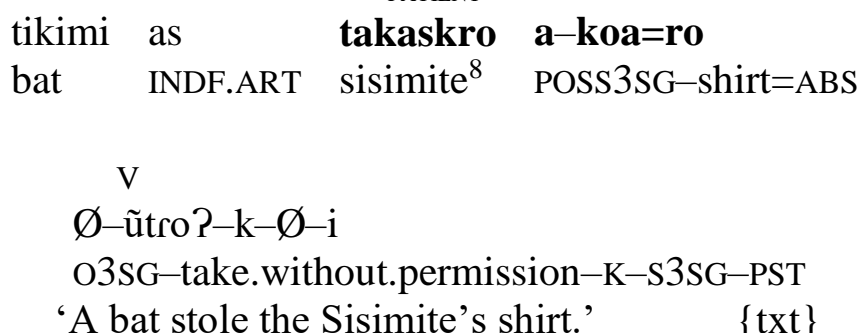

In (15) the O takaskro a-koa 'the Sisimite's shirt' is marked by the absolutive case marker as it introduces new information. In these types of clauses, the marked constituent functions as the prominent participant (in Lambrecht's [1994] sense of prominence) or the focus of the clause (see Chamoreau 2018).

Thus the occurrences of case marking are infrequent in independent clauses and less common in subordinate clauses in which generally no noun phrase is used. ${ }^{9}$

Verb agreement in Pesh is compulsory and it shows a nominative-accusative alignment for indexing (see Section 3 for details). The sole argument of an intransitive verb is encoded by a suffix, as illustrated by the third person plural -er in (16).

Carbón

(16) akafki waha te $-\mathbf{e r}-\mathbf{i}$

thus forest walk-S3PL-PST

'Thus, they walked in the forest.' $\{\mathrm{txt}\}$

The A of monotransitive verbs, as in (17), and ditransitive verbs, as in (18), are obligatorily encoded on the verb by a suffix, as illustrated by the third person plural suffix -er.

\section{Carbón}

(17)

$\begin{array}{lll}\text { ta-wahwã=hã } & \text { akwa=ma } & \varnothing-\text { proh-er }- \text { tW-wa } \\ \text { POSS1-grandson=FOC } & \text { other=TOP } & \text { O3SG-look.for-S3PL-NEG-PFV }\end{array}$

'My grandsons didn't look for other people.' $\quad\{\mathrm{txt}\}$

\footnotetext{
${ }^{8}$ The "Sisimite" is an important mythological figure similar to Bigfoot whom the Pesh people fought against.

${ }^{9}$ In a first approach, I count the NPs marked by case markers in a text sample (narratives, conversations, and so on) of 6582 clauses of which 1476 are intransitive, 798 have non-verbal predicates and 4308 are transitive. In total, $3.5 \%$ of S arguments (pronouns and NPs) of intransitive verbs are marked by the absolutive case marker, and the same percentage occurs for non-verbal predicates; $4.5 \%$ of A arguments are marked by the ergative case marker; and $6.5 \%$ of $\mathrm{O}$ arguments are marked by the absolutive or accusative case marker. The distribution by variety is as follows: for the variety of Culmi, no $\mathrm{S}$ is marked, $5 \%$ of $\mathrm{A}$ arguments and $6.5 \%$ of $\mathrm{O}$ arguments are overtly marked, by the ergative and accusative markers respectively; for the variety of Carbón, 7\% of S arguments (of intransitive verbs) are marked and $6.5 \%$ of S arguments (of non-verbal predicates) are marked by the absolutive marker; $3.5 \%$ of $\mathrm{A}$ arguments are marked by the ergative marker, and $6.5 \%$ of $\mathrm{O}$ arguments are marked by the absolutive marker.
} 
Culmi
(18)
$\begin{array}{lllll}\tilde{a}=y a ̃ & \text { kãs } & \text { to? } & \text { arwã } & \text { ka-wif-k-er-i } \\ \text { DEM.DIST=LOC } & \text { donkey.tiger }^{10} & \text { DEM.MED } & \text { man } & \text { O3PL-give.O3-K-S3PL-PST }\end{array}$
kadena - ah $=$ yo
chain-NMLZ=INS
'There, they gave the donkey-tiger with chains to these men.' $\{$ txt $\}$

The $\mathrm{O}$ is obligatorily encoded by a prefix, as illustrated by the third person plural prefix $k a$ - in a ditransitive verb as in (18) above, and in a monotransitive verb, as in (19).

Culmi

$\begin{array}{llllc}\tilde{a}=\text { ma } & \text { ke } & \text { swara } & \text { pe=ra } & \text { ka-ũweh-i-i } \\ \text { DEM.DIST=TOP } & \text { already } & \text { old.woman } & \text { only=ACC } & \text { O3PL-gather-S3SG-PST } \\ \text { 'That one gathered only the old women together.' } & \{\text { txt }\}\end{array}$

In the case of a ditransitive verb, as in (18), Pesh exhibits a secundative alignment (or primary object alignment) for indexing: the participant that can be encoded is the recipient, to? arwa 'these men' in (18), while the theme, kãs 'the donkey-tiger' in (18), cannot be encoded (Chamoreau 2017).

Pesh has a topic marker $=m a$ that is usually correlated with thematic discontinuity or referent complexity - that is, with the need to encode the topic to maintain discourse coherence (Chamoreau 2020b). It may indicate a continuing, shifted, or contrastive topic and it may also be used for frame-setting topics. The noun phrase that contains the topic is usually left-dislocated, and when multiple arguments are attested in a sentence, it occurs as the first noun phrase. In (20), the O piwa 'your husband' is left-dislocated and marked by the topic marker, since this noun phrase represents a shift in topic. It is positioned before the A $a$-kaki 'the mother of the fishes'.

Carbón
pi-wa=ma
wifã a-kaki=ya
$\varnothing-\mathrm{pa}-\mathrm{k}-\varnothing-\mathrm{i}$
POSS2-husband=TOP
fish POSS3SG-mother=ERG
O3SG-take-K-S3SG-PST

'As for your husband, the mother of the fishes took him.' $\{\mathrm{txt}\}$

When =ma is used with a core argument, such as an O, as in (20), it is impossible to add the case marker. The topic marker $=m a$ is used alone. In contrast, in a postpositional phrase, when the topic is an oblique or adjunct constituent, such as the locative in (21), the string with the case enclitic and the enclitic $=m a$ is obligatory.

\section{Culmi}

(21)

$\begin{array}{lll}\tilde{\mathbf{a}}=\mathbf{y} \tilde{\mathbf{a}}=\mathbf{m a} & \mathrm{se} & \mathrm{t} \int \mathrm{a}-\varnothing-\mathrm{tW}-\mathrm{wa} \\ \text { DEM.DIST=LOC=TOP } & \text { peacock } & \text { be.there-S3SG-NEG-PFV } \\ \text { 'There, there are no peacocks.' }\{\mathrm{txt}\}\end{array}$

\footnotetext{
${ }^{10}$ The donkey-tiger is a mythological figure that represents maliciousness.
} 


\section{Nominative-accusative pattern for obligatory verb-agreement affixes}

In this section I describe the obligatory verb agreement in Pesh, showing that all the varieties of Pesh exhibit a nominative-accusative pattern. A verb has two argument slots: the $\mathrm{O}$ is marked by a prefix and the $S$ and the $A$ by a suffix. The sole argument indexed in an intransitive verb is the $\mathrm{S}$, as illustrated by the first person $-a$ in (22) and the second person $-u$ in (23).

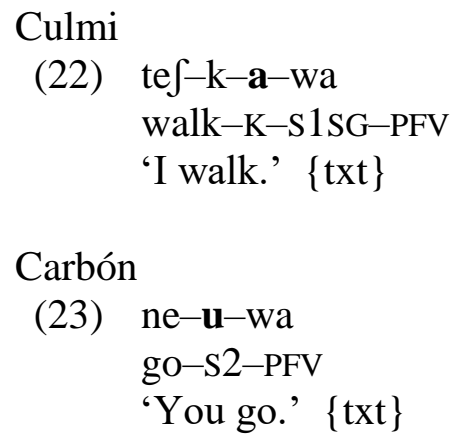

These markers are the same ones that are used to encode the A in a monotransitive verb; compare (22) with (24) and (23) with (25). In monotransitive verbs, the $\mathrm{O}$ is obligatorily marked, for example, the prefix for second person $p i$ - in (24) and the prefix for first person $t a$ - in (25).

Carbón

$$
\begin{aligned}
& \text { pi-pa-a-wa } \\
& \text { O2-take-S1SG-PFV } \\
& \text { 'I take you.' }\{\text { txt }\}
\end{aligned}
$$

\section{Carbón}

$$
\begin{aligned}
& \text { ta-we } \int-\mathrm{k}-\mathbf{u}-\text { ri } \\
& \text { o1-hear-K-s2-PST } \\
& \text { 'You heard me.' }\{\text { txt }\}
\end{aligned}
$$

The behavior is the same when the $\mathrm{S}$ and the $\mathrm{A}$ are third person. In intransitive verbs, the suffix for the $S$ is $-i$, as in (26). In monotransitive verbs, as illustrated in (27), the suffix for the $A$ is the same as in (26) and the prefix for the $\mathrm{O}$ is the first person $t a-$, as in (25).

Culmi

(26) te?-boh-n-i-wa

come-leave-DUR-S3SG-PFV

'He arrived.' $\{$ txt $\}$

\section{Carbón}

ta-proh-i-i

o1-look.for-S3SG-PST

'He looked for me.' $\{$ txt $\}$ 
In the case of ditransitive verbs, Pesh has a secundative alignment for indexing: the recipient is the only argument that can be encoded, as shown in (28) and (29), while the patient cannot. Thus, the $\mathrm{O}$ indexed on the verb is always the primary object.

Culmi

Ditransitive verb

(28) ta-tus tas ta-suwa Ø-wi $\int-\mathrm{k}-\mathbf{e r}-\mathrm{pi}$

POSS1-father PRO1 POSS1-grandmother O3SG-give.O3-K-S3PL-FUT

'My parents will entrust me to my grandmother.'

Culmi

(29)

ta-suwa $\quad$ ta-ãyh-er-i
POSS1-grandmother $\quad$ o1-give.O1:2-S3PL-PST
'They entrusted my grandmother to me.'

In all the varieties of Pesh, there are two sets of person markers, as shown in Table 1.

TABLE 1

PERSON MARKERS IN PESH

\begin{tabular}{|c|c|c|c|}
\hline & $\begin{array}{c}\text { Accusative set } \\
(\mathrm{O})\end{array}$ & & $\begin{array}{c}\text { Nominative set } \\
\text { (S/A) }\end{array}$ \\
\hline $1 \mathrm{SG}$ & ta- & & $-\mathrm{a}$ \\
\hline 1PL.INCL & pa- & & - par \\
\hline 1PL.EXCL & un- & & -bar / -ber \\
\hline \multirow[t]{2}{*}{$2 \mathrm{SG}$} & pi- & & $-\mathrm{u}$ \\
\hline & & PST.REC & $-\mathrm{i}$ \\
\hline \multirow[t]{3}{*}{$2 \mathrm{PL}$} & pi- $\ldots=$ wa & & $-\mathrm{u} \ldots=$ wa \\
\hline & & PST.REC & $-\mathrm{i} \ldots=$ wa \\
\hline & & PFV & $-\mathrm{u} \ldots=\mathrm{wi}$ \\
\hline $3 \mathrm{SG}$ & a- / Ø- & & $-\mathrm{i} /-\varnothing$ \\
\hline & & PST.REC & $-\mathrm{u}$ \\
\hline 3PL & ka- & & -er / -ir \\
\hline
\end{tabular}

Some variations have been noticed for S/A markers; these are generally conditioned by tense and aspect. For the second person the suffix by default is $-u$ in the singular and $-u \ldots=w a$ in the plural, the suffix $-i$ is only used with the recent past. The plural marker for second person by default is $=w a,=w i$ is only used with the perfective. For the third person singular the suffix by default is $-i$, and $-u$ is only used with the recent past. Some variations in vowel quality-for example, the first person plural exclusive or the third person plural-are due to the phonetic environment. For O markers, the first person singular prefix is $t a-$, while the plural is distinguished by adding the prefix $u n$ - (exclusive) or $p a$ - (inclusive). The second person plural $\mathrm{O}$ marker is distinguished from the corresponding singular by adding the enclitic $=w a$ at the end of the verb, as in (30). 
Culmi
pi-kapar-k-a-wa=wa
ta-arki
te?-ta-t $\int \mathrm{a}-\mathbf{u}-\mathrm{i}=\mathbf{w a}=$ ras
O2-thank-K-S1SG-PFV=2PL POSS1-man's.brother come-O1-see-S2-PST=2PL=REAS

'I thank you PL , brothers, because you ${ }_{\mathrm{PL}}$ came to see me here.' $\{\mathrm{txt}\}$

Whatever the tense or aspect, the pattern for verb agreement is always the same: compare the example in (29) in the past, with the example in (26) in the perfective, and the example in (28) in the future.

In mandatory verb agreement, Pesh shows morphological nominative-accusative alignment in all varieties and in all types of clause: subordinate clauses as in (30) above, interrogative content clauses as in (31) and relative clauses as in (32).

Culmi
ta $=$ yo
pẽh-ha
$\varnothing-$ tas $-\mathrm{k}-\mathbf{u}-\mathrm{ri}=\mathrm{sa}$
DEM.DIST=COM tree-NMLZ O3SG-cut $-\mathrm{K}-\mathrm{S} 2-\mathrm{PST}=\mathrm{C} . \mathrm{Q}$
'With whom did you cut the tree?' $\{$ txt $\}$

Culmi

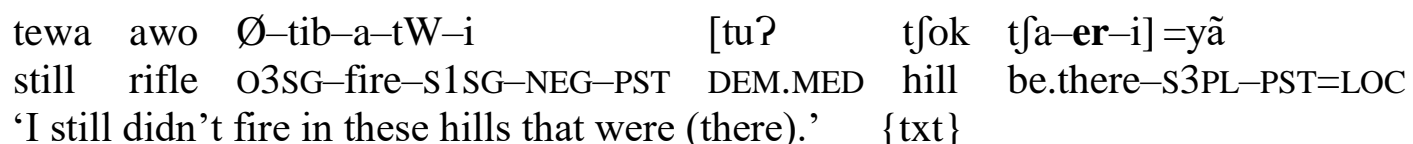

In Section 3, I showed that, in all the varieties of Pesh, the alignment is always nominativeaccusative for verb-agreement. In Sections 4, 5 and 6, I will demonstrate that the alignment is variable for case-marking on dependent constituents.

\section{Ergative-absolutive alignment in interrogative content clauses}

Three systems of alignment exist for flagging case: ergative-absolutive, tripartite, and nominative-accusative. The distribution of these three systems depends on the type of clause and the variety in question. In all Pesh varieties interrogative content clauses have ergativeabsolutive alignment and relative clauses have nominative-accusative alignment. In all other contexts, the dialects vary according to whether they require an ergative-absolutive or a tripartite system. In other words, we encounter two scenarios: (i) the Carbón dialect has two alignments: one general ergative-absolutive and one nominative-accusative only in relative clauses; and (2) the Culmi dialect has three alignments: one general which is tripartite, the ergative-absolutive in interrogative content clauses, and the nominative-accusative in relative clauses.

In this section, I describe the mandatory marking of the $w h$-word that introduces interrogative content clauses in Pesh. When asking questions about an argument, the presence of a case marker on the $w h$-word is mandatory. My hypothesis is that this obligation is motivated by the fact that the $w h$-word introduces the focus of the clause (see section 2). However, in Pesh, the marking seems to have become morphologized as it is mandatory. The selection of the case marker depends on the function of the argument in the clause and follows an ergative-absolutive pattern in all the varieties of Pesh.

Pesh makes use of two types of interrogative clause usually distinguishable by a predicate enclitic marker. The enclitic $=s a$ characterizes interrogative content clauses, as shown in (33). 
Culmi

(33)
$\tilde{\mathrm{i}}=\mathrm{ra} \quad \mathrm{a}-\mathrm{r}-\mathrm{ka}-\mathrm{i} \int-\mathrm{k}-\mathrm{i}-\int \mathrm{i}=\mathbf{s a}$
DEM.PROX $=$ ABS O3PL-APPL.P-make-DES-K-S3SG-PST.REC $=$ C.Q
'What did he want to hit?'
$\{t x t\}$

A comparison of (33) and (34) shows that only the presence of $=s a$ distinguishes the two clauses, and allows the interpretation of (33) as a content question and of $\tilde{l}=r a$ 'DEM.PROX=ABS' as a $w h$ word.

Culmi

$\begin{array}{ll}\tilde{\mathrm{i}}=\mathrm{ra} & \mathrm{a}-\mathrm{r}-\mathrm{ka}-\mathrm{i} \int-\mathrm{k}-\mathrm{i}-\mathrm{j} \mathrm{i} \\ \text { DEM.PROX=ABS } & \text { O3PL-APPL.P-make-DES-K-S3SG-PST.REC }\end{array}$

'He wanted to hit these.'

The enclitic $=r e ?$ characterizes polar interrogative clauses in the Carbón variety (35). ${ }^{11}$

\section{Carbón}

witfã $\varnothing-$ wi $\int-\mathrm{k}-\mathrm{u}-\mathrm{ri}=\mathrm{re} ?$

fish O3SG-give.O3-K-S2-PST=P.Q

'Did you give him the fish?' \{txt\}

A comparison of (35) and (36) shows that, in Carbón, only the presence of =re? distinguishes the two clauses, and allows the interpretation of (35) as a polar question.

\section{Carbón}

(36) yohra ka-wif-k-a-ri

yucca O3PL-give.O3-K-S1SG-PST

'I gave them yucca?' $\{$ txt $\}$

As shown in example (33), interrogative content clauses in Pesh take a $w h$-word. These $w h$ words are formed from five different sources, as shown in (37):

\footnotetext{
${ }^{11}$ In contrast, in the Culmi variety, polar interrogative clauses are not usually marked with any special enclitic. A final higher pitch distinguishes polar interrogative clauses, shown in (a), from declarative clauses. In the Culmi variety, the enclitic $=r e$ ? is used to express doubt about whether an event will happen or has happened. The verb is always marked by a negative morpheme in this construction, as shown in (b).

Culmi

(a) $\quad$ ikata $=$ ma $\quad \tilde{i}=$ na $\quad \varnothing-u P t \int a h-i-t \int j$

nOw $=$ TOP DEM.PROX $=$ INDF O3SG-sell-S2-PST.REC

'Did you sell something today?' $\quad\{\mathrm{txt}\}$ (pronounced with final higher pitch)

Culmi

(b) yuku=ra $\quad \varnothing-\mathrm{kuh}-\mathrm{u}-\mathrm{tW}-\mathrm{fi}=\mathrm{re} \quad \quad$ kapani meat $=$ ACC $\quad$ O3SG-buy-S3-NEG-PST.REC $=$ P.Q morning

'Didn't he buy the meat this morning?' $\{\mathrm{txt}\}$
} 
1. ta DEM.DIST for 'who' [+ HUM]

2. $\tilde{l}$ DEM.PROX for 'what, how, why, when' [- HUM]

3. $\tilde{a}$ DEM.DIST for 'when'

4. $p i$ the verb 'place, put down' for 'where, which'

5. pif 'how many, how much'

The complete list of the eighteen $w h$-words in Pesh is given in Table 2 .

TABLE 2

LIST OF WH-WORDS IN PESH

\begin{tabular}{|c|c|c|c|}
\hline Basic meaning & $\begin{array}{l}\text { Further } \\
\text { specifications }\end{array}$ & Pesh wh- & Glosses \\
\hline \multirow[t]{6}{*}{ WHO } & 'who' + V VR & $t a=y a$ & DEM.DIST=ERG \\
\hline & $\begin{array}{l}\text { 'who' }+v_{\text {INTR }} \\
\text { 'to whom' }+v_{\text {TR }}\end{array}$ & $\mathrm{ta} a \mathrm{ra} / \mathrm{ta}=\mathrm{ro}$ & DEM.DIST $=$ ABS \\
\hline & 'with whom' & $t a=y o$ & DEM.DIST=COM/INS \\
\hline & 'in whose house' & $t a=y \tilde{a}$ & DEM.DIST=LOC \\
\hline & 'like who' & $\mathrm{t} a=\mathrm{kan} / \mathrm{t} a=\mathrm{ken}$ & DEM.DIST=SIM \\
\hline & 'whose'+ NP & ta-Peh & DEM.DIST=POSS.PRO \\
\hline \multirow[t]{3}{*}{ WHAT } & 'what'+ $\mathrm{V}_{\mathrm{TR}}$ & $\tilde{\imath}=y a$ & DEM.PROX=ERG \\
\hline & & $\tilde{l}=r a / \tilde{l}=r o$ & DEM.PROX $=A B S$ \\
\hline & 'with what' & $\tilde{l}=y o$ & DEM.PROX=COM/INS \\
\hline HOW & & $\tilde{l}=\mathrm{kan} / \tilde{l}=\mathrm{ken}$ & DEM.PROX=SIM \\
\hline WHY & & $\tilde{i}=r e \int$ & DEM.PROX=REAS \\
\hline \multirow{2}{*}{ WHEN } & ‘when’ (PST) & $\tilde{l}=$ kawar & DEM.PROX=? \\
\hline & 'when' (PFV/FUT) & $\tilde{a}=h \tilde{\imath}$ & DEM.DIST=? \\
\hline AT WHAT TIME & & $\tilde{a}-p e=r i$ & $\begin{array}{l}\text { DEM.DIST- } \\
\text { time }=\text { TEMP/MAN }\end{array}$ \\
\hline WHERE & & $\begin{array}{l}p i-a h \\
p i=k a n / p i=k e n\end{array}$ & $\begin{array}{l}\text { place-NMLZ } \\
\text { place=SIM }\end{array}$ \\
\hline WHAT/WHICH & & $p i-a h=r a / p i-a h=r o$ & place-NMLZ $=A B S$ \\
\hline HOW MUCH/MANY & & pif & \\
\hline
\end{tabular}

To form $w h$-words, the case marker is combined with the demonstratives, as shown in (33), or a nominalizer may be combined with a verb, as illustrated by pi-ah 'what, which', as shown in (38).

Culmi

$$
\begin{array}{ll}
\mathbf{p i - a h}=\mathbf{r a} & \varnothing-\mathrm{kuh}-\mathrm{i}-\mathrm{-} \mathbf{i}=\mathrm{sa} \\
\text { place-NMLZ=ABS } & \text { O3SG-buy-S2-PST.REC=C.Q } \\
\text { 'Which one did you buy?' } \quad\{\text { txt }\}
\end{array}
$$

For some $w h$-words, instead of a case marker, either a possessive or a nominalizer is used, as shown in (39) and (40) respectively (Chamoreau 2020a). 


\section{Carbón}

(39)

$$
\begin{array}{lll}
\text { ta-Peh } & \text { arwã=ro waha=yã nã- } \varnothing-\mathrm{i}=\mathrm{sa} \\
\text { DEM.DIST-POSS.PRO } & \text { man=ABS hill=LOC go-S3SG-PST=C.Q } \\
\text { 'Whose man went to the hill?' ('the father of whom') } & \text { \{txt }
\end{array}
$$

Culmi

$$
\begin{array}{lll}
\text { pi-ah } & \text { nã-u-pi=sa } & \text { t } \int \mathrm{a} \\
\text { place-NMLZ } & \text { go-S2-FUT=C.Q } & \text { tomorrow } \\
\text { 'Where will you go tomorrow?' } & \{\text { txt }\}
\end{array}
$$

A wh-word must occur in clause-initial position, never in situ. The predicate usually occurs at the right edge and is obligatorily marked by the content question marker $=s a$. Depending on information structure, some constituents may appear after the predicate, as shown in (40) with an adverb.

The pattern of alignment used in interrogative content clauses is ergative-absolutive whatever the variety. I illustrate this pattern with examples from Culmi, which has tripartite alignment in (non-interrogative) independent and subordinate clauses (see Section 5.2). The $w h$ word that asks about the $\mathrm{A}$ is formed with the ergative case marker, as in (41).

Culmi

(41) A

$$
\begin{array}{ll}
\text { ta }=\mathbf{y a} & \text { pi }-\mathrm{ka}-\mathrm{u}-\mathrm{si}=\mathrm{sa} \\
\text { DEM.DIST=ERG } & \text { O2-make-S3SG-PST.REC }=\mathrm{C} \cdot \mathrm{Q}
\end{array}
$$

'Who struck you?' $\{$ txt $\}$

The absolutive case marker $=r a$ is used to form the $w h$-word that asks about the $\mathrm{S}$, as in (42).

Culmi

(42) $\mathrm{S}$

$$
\begin{array}{lll}
\mathbf{t a}=\mathbf{r a} & \mathrm{t} \int \mathrm{a} \mathbf{P}-\varnothing-\mathrm{wa}=\mathrm{sa} & \text { to } \mathrm{P}=\mathrm{ya} \\
\text { DEM.DIST=ABS } & \text { be.there-S3SG-PFV=C.Q } & \text { DEM.MED=LOC }
\end{array}
$$

'Who is living there?' $\{\mathrm{txt}\}$

The absolutive case marker is also used to form the $w h$-word that asks about the $\mathrm{O}$, either the patient, as in (43), the theme or the recipient, as shown in (44).

Culmi

$$
\begin{aligned}
& \text { O-Patient } \\
& \text { pi-ah=ra } \quad \varnothing-k u h-i-\int i=s a
\end{aligned}
$$$$
\text { place }-\mathrm{NMLZ}=\mathrm{ABS} \quad \mathrm{O} 3 \mathrm{SG}-\mathrm{buy}-\mathrm{S} 2-\mathrm{PST} . \mathrm{REC}=\mathrm{C} \cdot \mathrm{Q}
$$

'Which one did you buy?' $\{\mathrm{txt}\}$ 
Culmi

(44) O-Recipient

$$
\begin{array}{lll}
\text { ta }=\text { ra } & \text { ka-ka-pe?-k-u-ri=sa } & \text { utfã } \\
\text { DEM.DIST=ABS } & \text { O3PL-APPL.R-bring-K-S2-PST=C.Q } & \text { fish } \\
\text { 'For whom } & \text { did you }{ }_{\mathrm{SG}} \text { bring the fish?' }\{\text { txt }\}
\end{array}
$$

Whatever the tense or aspect, the pattern is always the same: compare the example in (43) in the recent past, with the example in (42) in the perfective, and the example in (44) in the past.

To sum up this section: case markers on $w h$-words are obligatory and the selection of the marker depends on the function of the argument in the clause and follows an ergative-absolutive pattern in all the varieties of Pesh. The obligatory use of the marker and the stability of treatment in all the varieties reveal a well-established morphological pattern in Pesh. This construction is relevant for supporting the hypothesis that the ergative-absolutive is the original pattern of morphological alignment (Section 5.3).

\section{Alignment in independent and subordinate clauses in different varieties of Pesh}

In this section I describe the patterns where independent and subordinate clauses behave in the same manner. In both contexts, there are different patterns shown by each of the two varieties: an ergative-absolutive pattern in the Carbón variety and a tripartite pattern in the Culmi variety. However, in both varieties of Pesh, case-marking is variable. It is motivated by information structure - the case marker is usually used to emphasize that the marked constituent functions as the prominent participant or the focus.

\subsection{Ergative-absolutive alignment in the variety spoken in Carbón}

In the Carbón variety, the $\mathrm{A}$ of a monotransitive verb may be indicated by the ergative marker $=y a(45)$. In the example, the focalization of the A argument is shown by the postverbal position and the use of the ergative marker $=y a$.

Carbón

Monotransitive verb

$$
\begin{array}{lll}
\varnothing-\mathrm{pa}-\mathrm{k}-\mathrm{ak}-\varnothing-\mathrm{i}=\text { na } & \text { to? } & \text { wifã } \text { a-kaki=ya } \\
\text { O3SG-take-K-state-S3SG-PST=REP } & \text { DEM.MED fish POSS3SG-mother=ERG } \\
\text { 'They said that the mother of the fishes had already taken him.' }\{\text { txt }\}
\end{array}
$$

In contrast, the $\mathrm{S}$ may be marked by the absolutive marker $=r o$, as in (46) and (47).

\section{Carbón}

Active intransitive verb

$$
\begin{aligned}
& \text { aso=ro taweh- } \varnothing-\text { pi=hã } \\
& \text { water=ABS climb-S3SG-FUT=FOC } \\
& \text { 'The water will go up.' } \quad\{\text { txt }\}
\end{aligned}
$$


Carbón

Stative intransitive verb
$\tilde{a}=y a ̃$
$\mathrm{t} \int \mathrm{a}-\varnothing-\mathrm{i}$
pi-kõre $=$ ro $=$ hã
DEM.DIST $=$ LOC be.there - S3SG-PST POSS2-uncle $=$ ABS $=$ FOC
'It was your uncle who was there.' $\{\mathrm{txt}\}$

The use of the marker $=$ ro occurs when the $\mathrm{S}$ is focalized or prominent and is possible with an active verb, as in (46), and a stative verb, as in (47). In this paper, I studied the dichotomy between active and stative verbs in order to verify the specific behavior of each type of intransitive verb as Holt (1999:71) had postulated that this dichotomy could play a role in the use of $=r a$ with the $\mathrm{S}$ (Section 1).

The absolutive marker $=r o$ is used with the $\mathrm{O}$ of a monotransitive verb, as shown in (48).

\section{Carbón}

Monotransitive verb

$$
\begin{array}{lll}
\text { pi-proh-er-pe } & \text { pa } & \text { pe=ro } \\
\text { O2-look.for-S3PL-FUT } & \text { PRO2 } & \text { only=ABS }
\end{array}
$$

'They will look only for you.' $\{\mathrm{txt}\}$

The absolutive marker =ro may be used with either $\mathrm{O}$ argument of a ditransitive verb, as illustrated in (49) where it marks the benefactive and in (50) where it marks the theme. In a ditransitive clause, Pesh exhibits neutral alignment for flagging as the same absolutive marker $=r o$ is used for both types of $\mathrm{O}$ argument (theme and recipient, or benefactive, as in (49)).

\section{Carbón}

Ditransitive verb

DEM.DIST man=ABS O3SG-make-S3SG-PST=REP fish POSS3SG-mother=ERG

'They said that it was this man to whom the mother of the fishes did it. $\{\mathrm{txt}\}$

Carbón

Ditransitive verb

$$
\begin{array}{lll}
\text { pe } \int-\mathrm{kaki}=\text { ma } & \text { kaya-s=ro } & \mathrm{ka}-\mathrm{Pi}-\mathrm{k}-\varnothing-\mathrm{pi} \\
\text { POSS3PL-mother=TOP } & \text { story-INDF.ART=ABS } & \text { O3PL-tell-K-S3SG-FUT } \\
& & \\
\text { a-ye?-ler } & & \\
\text { POSS3SG-small-PL } &
\end{array}
$$

'This is a story that the mother will tell to her children.' $\quad$ txt $\}$

The ergative pattern is attested in Carbón whatever the tense and aspect, for example past in (49), perfective in (51) and also future in (50). This pattern of alignment holds for free pronouns, as in (48) and (51), and for NPs, as in (49) and (50). 
Carbón

$\begin{array}{llll}\text { (51) } \varnothing-\text { yẽh-er-tW-i } & {[\text { tas=ro }} & \text { tus } & \text { iwa=r-a-wa=ras }] \\ \text { O3SG-say-S3PL-NEG-PST } & \text { PRO1=ABS } & \text { father } & \text { owner=COP-S1SG-PFV=REAS }\end{array}$

'They don't talk because I am the father-owner.' [not you] $\{\mathrm{txt}\}$

The ergative marker is also attested in subordinate clauses although examples are scarce because of the infrequency of NPs that express arguments in this context, perhaps due to the tendency of subordinate clauses not to have information structure which differs from that of the matrix clause. In subordinate clauses, generally the verb occurs alone. For the ergative marking of the A, see example (52).

Carbón

$\begin{array}{lll}\text { [tẽytawa }=\text { ma } & \text { ye } \mathrm{P}=\text { ya } & \text { ka-puru-pif-k-er-pi=mã }] \\ \text { friend=TOP } & \text { small=ERG } & \text { O3PL-look.for-protect-K-S3PL-FUT=when }\end{array}$

ka-puru-pif-k-er-wa

O3PL-look.for-protect-K-S3PL-PFV

'When the boys should help their friends, they help them.' $\{\mathrm{txt}\}$

Example (51) illustrates a case of the absolutive marker being used for the $\mathrm{S}$ in a subordinate clause. In (53) the absolutive marker is applied to the O-patient of the monotransitive verb.

Carbón

[patawa $=$ pe $=\mathbf{r o}=$ hã $\quad$ ka-proh $-\varnothing-\mathrm{i}=$ tani] $\quad$ kat $-\varnothing-\mathbf{i}$ armadillo $=$ only $=\mathrm{ABS}=\mathrm{FOC} \quad 3 \mathrm{PL}-$ look.for $-\mathrm{s} 3 \mathrm{SG}-\mathrm{PST}=$ as.soon.as keep.quiet $-\mathrm{s} 3 \mathrm{SG}-\mathrm{PST}$ 'As soon as he looked for armadillos only, he kept quiet.' $\{\mathrm{txt}\}$

\subsection{Tripartite alignment in the variety spoken in Culmi}

In the Culmi variety, three different case markings are attested: the ergative marker $=y a$ with the $\mathrm{A}$, the accusative marker =ra with the $\mathrm{O}$, and the absence of marking with the $\mathrm{S}$. This type of marking is known as tripartite alignment. The use of an overt case-marker for $\mathrm{A}$ and $\mathrm{O}$ is variable in Culmi and is triggered, as in Carbón, by information structure.

The $\mathrm{S}$ of active and stative intransitive verbs is never marked, as illustrated by $\tilde{u} t \tilde{a}$ ' fish' in (54) and ye? 'children' in (55).

Culmi

(54) Active intransitive verb ã $\quad$ ũt ã te?-nã-er-ri

DEM.DIST fish come-go-S3PL-PST

'These fishes came and went away.' $\{\mathrm{txt}\}$ 
Culmi

(55) Stative intransitive verb
to? ye? $\tilde{a}=$ yã
t $\int a$ P-er-ri
$\varnothing$-we $\int-\mathrm{k}-\mathrm{er}-\mathrm{pi}=\mathrm{ra}$
DEM.MED small DEM.DIST=LOC be.there-S3PL-PST O3SG-hear-K-S3PL-FUT=PURP
'These children lived there for listening (to the language).' $\{\mathrm{txt}\}$

The absolutive marker $=r a$, illustrated in (56a) and (56b), is ungrammatical in the Culmi variety, even though it occurs in Carbón, and despite the fact it was accepted in the seventies in the Culmi variety, according to Holt (1999:71, see Section 1).

Culmi

a. *ã ũtfã =ra te?-nã-er-ri

Intended reading: 'These fishes came and went away.'

b. *to? ye?=ra ã=yã t $\int a ?-$ ir-ri $\emptyset$-we $\int-k-e r-p i=r a$ Intended reading: 'These children lived there for listening (to the language).'

I also proposed the marker $=y a$ to my collaborators to verify that the alignment is not nominative-accusative, as in (56c) and (56d), but this marker is also ungrammatical with an intransitive verb.

Culmi
c. *ã ũt $\tilde{a}=y a$ te?-nã-er-ri
Intended reading: 'These fishes came and went away.'

d. *to? ye?=ya ã=yã t $\int \mathrm{a} ?-\mathrm{ir}-\mathrm{ri} \quad \emptyset$-we $\int-\mathrm{k}-\mathrm{er}-\mathrm{pi}=\mathrm{ra}$

Intended reading: 'These children lived there for listening (to the language).'

The A may be marked with the ergative marker =ya, as Juana (57) in a monotransitive clause and $y e$ ? ' girl' in (58) in a ditransitive clause.

Culmi

(57)

\begin{tabular}{llll}
\multicolumn{2}{c}{ Monotransitive verb } & & \\
te $\mathrm{P}-\mathrm{k}-\mathrm{ir}-\mathrm{i}$ & sira=ma & juana=ya & $\varnothing-\mathrm{kaP}-\mathrm{i}-\mathrm{i}=\mathrm{ras}$ \\
come-K-S3PL-PST & meal=TOP & Juana=ERG & O3SG-make-S3SG-PST=REAS
\end{tabular}

'They came because of the meal, Juana made it.' $\quad\{\mathrm{txt}\}$

Culmi

(58) Ditransitive verb

$\begin{array}{lll}\text { a }- \text { suwa }=\text { ra } & \text { ye } P=\text { ya } & \text { ti }-\varnothing-\mathrm{k}-\varnothing-\mathrm{i}=\text { na } \\ \text { POSS3SG-grandmother }=\text { ACC } & \text { small=ERG } & \text { say }-O 3 S G-K-S 3 S G-P S T=R E P\end{array}$

'To her grandmother, they said that the girl said ...' $\{$ txt $\}$

The accusative marker $=r a$ is used with the $\mathrm{O}$ of a monotransitive verb, as yo?ra 'yucca' as shown in (59). The presence of the accusative marker $=r a$ is variable and depends on information structure. 
Culmi

(59) Monotransitive verb

$$
\text { sira } \varnothing \text {-ũweh-er-pe } \quad \text { yohra=ra kre } \int
$$

food O3SG-collect-S3PL-FUT yucca=ACC more

'They will collect food, more yucca.' $\quad\{\mathrm{txt}\}$

The accusative marker $=r a$ is also used with both $\mathrm{O}$ arguments of a ditransitive verb, as illustrated by the theme yoPra 'yucca' in (60) and the addressee suwa 'grandmother' in (58).

Culmi

(60) Ditransitive verb

$$
\begin{array}{ll}
\text { yo } P \text { ra }=\text { ra } & \text { pi-ka-kuh-a-peP-k-a-ri } \\
\text { yucca }=\text { ACC } & \text { O2-APPL.R-buy-S1sG-bring-K-S1SG-PST }
\end{array}
$$

'I bought and I brought to you the yucca.' $\{\mathrm{txt}\}$

The tripartite pattern is also used with subordinate clauses, though examples are infrequent, for the same reasons the use of ergative patterns in these clauses in Carbón are infrequent (see Section 5.1). The $\mathrm{S}$ is unmarked, as in (61), while the A can be marked by the ergative marker $=y a$, illustrated in example (62).

Culmi

(61)
[tas apif-k-a-wa=tani]
$\varnothing$-eye $-\mathrm{k}-\mathrm{er}-\mathrm{wa}$
PRO1 lie.down-K-S1SG-PFV=as.soon.as
$\mathrm{O} 3 \mathrm{SG}-$ sing $-\mathrm{K}-\mathrm{S} 3 \mathrm{PL}-\mathrm{PFV}$
'As soon as I go to bed they sing.' $\{\mathrm{txt}\}$

Culmi

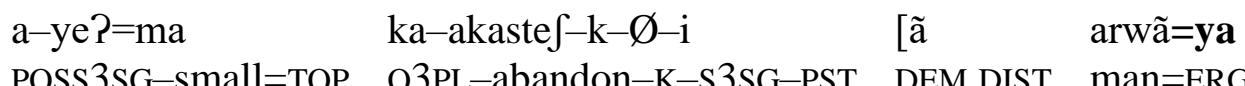

$$
\begin{aligned}
& \text { korta akwa=yo nã- } \varnothing-\mathrm{i} \quad \mathrm{a}-\mathrm{po}-\mathrm{k}-\varnothing-\text {-wa }=\text { ras }] \\
& \text { woman other=COM go-S3SG-PST REFL-put-K-S3SG-PFV=REAS }
\end{aligned}
$$

'He abandoned the children because that man went and he put himself with another woman.' $\{\mathrm{txt}\}$

The $\mathrm{O}$ can be overtly marked by the accusative marker $=r a$, as in (63).

Culmi

$$
\begin{aligned}
& \text { [korta } \left.=\mathbf{r a} \quad \text { te } 2-\mathrm{a}-2 \mathrm{i} \int-\mathrm{k}-\varnothing-\mathrm{wa}=\mathrm{mã}\right] \\
& \text { woman }=\mathrm{ACC} \quad \text { come }-\mathrm{O} 3 \mathrm{SG}-\text { tell }-\mathrm{K}-\mathrm{S} 3 \mathrm{SG}-\mathrm{PFV}=\text { when } \\
& \mathrm{a}-\mathrm{Pi} \int-\mathrm{k}-\varnothing-\mathrm{i}=\mathrm{na} \quad \text { tas }=\mathrm{ma} \quad \text { as }=\mathrm{pe} \quad \text { te }-\mathrm{k}-\mathrm{a}-\mathrm{wa} \\
& \text { O3SG-tell-K-S3SG-PST }=\text { REP } \quad \text { PRO1 }=\text { TOP } \quad \text { one }=\text { only } \quad \text { come }-\mathrm{K}-\mathrm{S} 1 \mathrm{SG}-\mathrm{PFV}
\end{aligned}
$$

'When he arrived to advise the woman, he said: "I come alone".' $\{\mathrm{txt}\}$ 
The tripartite alignment is used whatever the tense or aspect - an example with the perfective was given in (63), with the past in (60), and with future in (59).

\subsection{Summary}

In Section 5, I demonstrated that two types of alignment exist with independent and subordinate clauses: an ergative-absolutive pattern in the Carbón variety and a tripartite pattern in the Culmi variety. In the ergative-absolutive pattern, each argument receives a specific morphological marker, but in the tripartite pattern, the $\mathrm{A}$ and the $\mathrm{O}$ of a transitive verb are overtly marked while the $S$ receives no additional morphology. In both varieties, the overt case marking is not obligatory for $\mathrm{A}$ and $\mathrm{O}$, and $\mathrm{S}$ in the Carbón variety. In Pesh, this pattern is perhaps due to the mandatory verb-agreement pattern and the expected and frequent verb-final constituent order, frequently AOV order. The change in order is generally the result of a modification in information structure - that is, the marking of the prominence of an argument. Usually this change triggers the use of a case marker. The case marker may also be used with AOV order for reasons of information structure (see Section 2).

It is cross-linguistically uncommon for both argument case markers to not be obligatory (Malchukov 2017; Fauconnier and Verstraete 2014). Variable ergative marking has been described in ergative languages, and is often linked to information structure, with the presence of the ergative resulting from the constituent's prominence (McGregor and Verstraete 2010; Fauconnier and Verstraete 2014; Schultze-Berndt 2017). In contrast, non-obligatory absolutive marking is scarce in ergative languages. Cross-linguistically, S arguments are more often than not zero-marked so variable marking is rare for that reason. Non-obligatory absolutive marking is attested at least in East Caucasian languages, for instance in Udi (Schulze 2009).

In Pesh, the question of the relation between the ergative pattern and the tripartite pattern arises, since these two alignments are used in the same context but in different varieties. It can be postulated that ergative-absolutive is the original alignment for argument case markers in independent and subordinate clauses. Two arguments support this hypothesis. Firstly, the ergative-absolutive pattern is also used in obligatory case marking in interrogative content clauses in all the dialectal varieties (see Section 4). Secondly, Holt's examples $(1999: 71,79)$ reproduced in (2) and (4) show that it was possible in the seventies in the Culmi variety to use the marker $=r a$ with the $\mathrm{S}$ of an intransitive verb. These examples are rejected now and described as ungrammatical in the Culmi variety. This variety seems to have modified the alignment pattern.

The hypothesis that the tripartite pattern used in the Culmi variety, which results in the absence of an overt marker on the $\mathrm{S}$, can be analyzed as an evolution of the ergative-absolutive pattern is supported, first by the pattern of non-obligatory marking for arguments, second by the parameter of low transitivity of the intransitive verb and third, by the absence of the necessity of the marking of the $\mathrm{S}$. These two last features are cross-linguistically frequent. The evolution from ergative-absolutive alignment to a tripartite pattern has been reported in other languages, such as Chibchan Bribri (Quesada 1999), Mayan Ch'orti' (Quizar 1979), certain Australian languages (Austin 1981), and Caucasian Udi (Schulze 2009). 


\section{Nominative-accusative alignment in relative clauses}

In this section, I describe the alignment pattern used in relative clauses. In Pesh, relative clauses are relevant for the analysis of morphological alignment as the constructions essentially use case markers. The nominative-accusative pattern shown in this type of clause is directly related to topicality, as the marker $=m a$ that is used for $\mathrm{S}$ and $\mathrm{A}$ has the same form as the topic marker, and seems to have evolved from topic marker to nominative marker.

In all the varieties, Pesh follows three relativization strategies: 1) internally-headed relative clauses, in which the head nominal of the relative clause is a core argument or a genitive (possessor) and occurs inside the relative clause - this is the most frequent and primary strategy in Pesh, as it is used to relativize subjects. The enclitic that mandatorily occurs at the end of the $\mathrm{RC}$ may be a case marker or the topic marker. It corresponds to the syntactic role of the head nominal in the matrix clause; 2) externally-headed relative clauses in which the head nominal, which has a peripheral role in the relative clause, occurs outside the relative clause. The case marker that obligatorily occurs at the end of the RC corresponds to the syntactic role of the head nominal in the RC; and 3) relative clauses introduced by a $w h$-word that functions as a relative marker - only locative wh-words piah 'where' and pikan 'where, in which direction' occur in this construction.

The distribution of the three relative clauses in Pesh clearly responds to accessibility restrictions on specific functions: arguments and genitive with internally-headed relative clauses, oblique and adjunct (comitative, instrumental, locative, and object of comparison) with externally-headed relative clauses, and locative with $w h$-RCs. As this paper is concerned with the pattern of argument marking, I only focus on internally-headed relative clauses (see Chamoreau 2020a; also Chamoreau forthcoming for the other strategies).

An internally-headed relative clause occurs when the head nominal has the role of a core argument or a genitive in the relative clause, as in (64).

Culmi

Nominal: $\mathrm{O}$ in the $\mathrm{RC}-\mathrm{A}$ in the $\mathrm{MC}$
[ta-arwã waka
pok
ka-kuh- $\varnothing-\mathrm{i}]=\mathbf{m a}$
ka?-ye?-er-i
POSS1-man cow
two O3PL-buy-S3SG-PST=NOM
make-small-S3PL-PST
'The two cows my husband bought gave birth.' $\{\mathrm{Txt}\}$

The enclitic that obligatorily occurs at the end of the relative construction may be a case marker or the topic marker $=m a$. It corresponds to the syntactic role of the head nominal in the matrix clause. In internally-headed relative clauses Pesh has a nominative-accusative pattern. This enclitic also demarcates the end of the relative clause (Chamoreau forthcoming).

The nominative-accusative alignment occurs when the function of the head nominal in the relative clause is an $\mathrm{A}$, as in (65a). 
Culmi

Nominal: $\mathrm{A}$ in the $\mathrm{RC}-\mathrm{S}$ in the $\mathrm{MC}$

$$
\begin{aligned}
& \text { a. îkita }=\text { ma }[\text { to ? ministro } \varnothing \text {-yẽh- } \varnothing-\text { wa }]=\text { ma } \\
& \text { now }=\text { TOP DEM.MED minister O3SG-say-S3SG-PFV=NOM } \\
& \text { te?-k- } \varnothing-\text { wa } \\
& \text { come-K-S3PL-PFV } \\
& \text { 'This minister who commands comes now.' }\{\mathrm{txt}\}
\end{aligned}
$$

When the head nominal functions as an $\mathrm{S}$ or an $\mathrm{A}$ in the matrix clause, the nominative marker $=m a$ appears compulsorily in relative clauses. With the $\mathrm{S}$, it is not possible to use the absolutive marker $=r o$ in the Carbón variety, as in example (65b), nor to omit a marker for an $\mathrm{S}$ in the Culmi variety, as in (65c). The sentence in $(65 b)$ was offered to the collaborators in both varieties to verify the use of the marker =ro in the context of a focus constituent - that is, the answer to the question in $(65 \mathrm{~d})$.

Carbón

(65) b. *ĩkita=ma [to? ministro $\varnothing-$ yẽh- $\varnothing-$ wa $]=$ ro te?-k- $\varnothing-$ wa

'This minister who commands comes now.'

Culmi

(65) c. *îkita=ma [to? ministro $\varnothing-$ yẽh- $\varnothing-$ wa $]$ te?-k- $\varnothing-$ wa

'This minister who commands comes now.'

Carbón and Culmi

$$
\begin{aligned}
& \text { d. ta=ro(ra) ilkita } \quad \text { te } P-\mathrm{k}-\varnothing-\mathrm{wa}=\mathrm{sa} \\
& \text { DEM.DIST=ABS now } \\
& \text { 'Who comes now?' }
\end{aligned}
$$

In the same way, the nominative-accusative alignment occurs when the function of the head nominal in the relative clause is an $\mathrm{O}$, as in (66a).

Culmi

Nominal: O-recipient in the $\mathrm{RC}-\mathrm{A}$ in the $\mathrm{MC}$

$$
\begin{aligned}
& \text { (66) a. [korta ĩsi tas a-ka-kuh-a-ri] }=\text { ma ket } \int a \\
& \text { woman medicine PRO1 O3SG-APPL.R-buy-S1SG-PST=NOM yesterday } \\
& \varnothing-\mathrm{ka}-\varnothing-\mathrm{i} \\
& \text { O3SG-make-S3SG-PST } \\
& \text { 'The woman from whom I bought the medicine made it yesterday.' }\{\mathrm{txt}\}
\end{aligned}
$$

In this context, it is not possible to use the ergative marker =ya in Carbón or in Culmi with the A, as in (66b), even if this is the answer to the question in (66c). 
Carbón and Culmi

(66) b. *[korta ĩsi tas a-ka-kuh-a-ri]=ya ket $\varnothing a$

'The woman from whom I bought the medicine made it yesterday.'

Carbón and Culmi

$$
\begin{array}{lll}
\text { c. } \quad \text { ta=ya } & \text { ket } \int \mathrm{a} & \emptyset-\mathrm{ka}-\varnothing-\mathrm{i}=\mathrm{sa} \\
\text { DEM.DIST=ERG } & \text { yesterday } & \text { O3SG-make-S3SG-PST=C.Q } \\
\text { 'Who made it yesterday?' } &
\end{array}
$$

In relative clauses, the marker $=m a$ marks the function of the nominative. In Section 2, =ma was described as a topic enclitic marker. Its function has evolved from topic-marking to subjectmarking.

When the head nominal functions as the O-patient in the matrix clause, the relative clause is marked by =ra in Culmi, as shown in (67), or =ro in Carbón, as shown in (68), regardless of its role in the relative clause.

Culmi

Nominal: A in the RC - O-patient in the MC

$$
\begin{array}{llll}
\text { [arwã } & \text { onih } & \text { ta-kaki } & \text { a-r-kapa } \int-\text { teP-nã-er-ri] }=\text { ra } \\
\text { man } & \text { dead } & \text { POSS1-mother } & \text { O3SG-APPL.P-speak-come-go-s3PL-PST=ACC }
\end{array}
$$

ka-proh-a-wa

O3PL-look.for-S1SG-PFV

'I looked for the dead men who came to speak to my mother and went away.' $\{\mathrm{txt}\}$

\section{Carbón}

Nominal: O-theme in the $\mathrm{RC}-\mathrm{O}$-patient in the $\mathrm{MC}$

$$
\begin{array}{llc}
{[\text { yuku }} & \varnothing-\mathrm{ka}-\mathrm{tuh}-\mathrm{u}-\mathrm{wa}]=\mathbf{r o} & \emptyset-\tilde{\mathrm{a}}-\mathrm{a}-\mathrm{tW}-\mathrm{wa} \\
\text { meat } & \text { O3SG-APPL.R-cook-S2-PFV=ACC } & \text { O3sG-eat-S1SG-NEG-PFV } \\
\text { 'I didn't eat the meat you cooked for him.' } & \{\text { txt }\}
\end{array}
$$

In the same way, the relative clause is marked by $=r a$ in Culmi or =ro in Carbón when the head nominal functions as the O-recipient in the matrix clause, as in (69a), regardless of its role in the relative clause.

Culmi

Nominal: A in the RC-O-recipient in the MC

$$
\begin{aligned}
& \text { a. tas }=\text { ma }[\text { kapan kapan korta ta-ye? } \\
& \text { PRO1=TOP morning morning woman POSS1-small } \\
& \varnothing-\mathrm{ka}-\mathrm{t} \tilde{\mathrm{a}}-\varnothing-\mathrm{pi}]=\mathrm{ra} \quad \quad \text {-wi } \int-\mathrm{k}-\mathrm{a}-\mathrm{ri} \\
& \text { O3SG-APPL.R-See-S3SG-FUT=ACC O3SG-give.O3-K-S1SG-PST } \\
& \text { 'I entrusted him to the woman who will take care of my son every morning.' }\{t x t\}
\end{aligned}
$$

The question in $(69 b)$ occurs just before the response in $(69 a)$ in this conversation. 
Culmi

(69)
b. ta=ra
pi-ye?-a
$\varnothing-$ wi $-\mathrm{k}-\mathrm{u}-\mathrm{ri}=\mathrm{sa}$
DEM.DIST=ABS POSS2-small-NMLZ 3SG-give.O3-K-S2SG-PST=C.Q

'To whom did you entrust your baby?' $\{\mathrm{txt}\}$

In (69a), the use of the marker =ra allows a focalization of the O. This is the same context as in (67) and (68). Although the use of the accusative enclitic marker is the most frequent pattern, the topic enclitic marker =ma may also be used, as shown in (70).

Culmi

Nominal: O-patient in the RC - O-patient in the MC

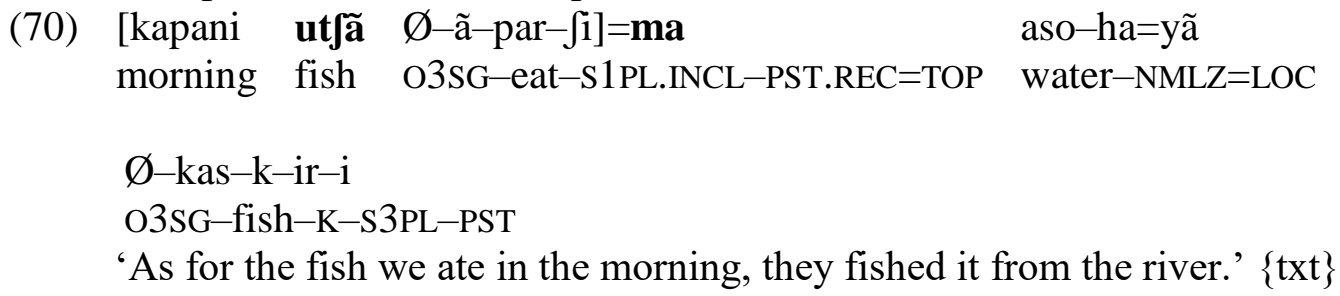

The distribution of these two markers is conditioned by information structure: when the accusative case is used, as shown in (69a), the nominal is focalized, and when the topic marker is used, as illustrated in (70), the nominal is topicalized. The possibility of choice between the case marker $=r a /=r o$ and the topic $=m a$ triggered by the information structure context allows the analysis of $=m a$ as topic in this context.

To sum up: the pattern shown by relative clauses is nominative-accusative in all the varieties. A case marker or the topic marker is obligatorily used. What is interesting is the use of $=m a$ to mark the relative clauses that function as S, A and genitive in the matrix clause. Relativization of the $\mathrm{S}$, the $\mathrm{A}$ and the genitive is related to topicality, as the marker $=m a$ has the same form as the topic marker and its function has evolved from topic-marking to subject-marking. The nominative-accusative pattern shown in relative clause is directly related to topicality as expressed at least by another Chibchan languages, Buglere (Quesada 2012). In Pesh, further evidence of this comes from (i) the constraints on the use of the marker $=m a$ for the relativization of the S, the A and the genitive; and (ii) the fact that the ergative marker cannot be used in this context (Chamoreau forthcoming; Shibatani 1991). On the contrary, for the O, the use of the accusative marker is the most frequent but if the $\mathrm{O}$ functions as the topic of the clause, the topic marker may be used. Pesh shows an S/A pivot for relative clauses.

\section{Nominative-accusative syntactic alignment}

Sections 3 through 6 described the morphological alignment patterns in Pesh through agreement (Section 3) and case marking (Sections 4, 5, and 6). In this section I analyze syntactic patterns of alignment by describing the syntactic behavior of the $\mathrm{S}$ along with that of either the $\mathrm{A}$ or the O. I will describe these properties of cross-clausal behaviors in two constructions: (i) the possibility of deletion of the $\mathrm{S}$ or the $\mathrm{A}$ in the second clause when two clauses are conjoined with coreferential subjects; and (ii) the control of coreference with core arguments in purpose clauses. This section is concerned with the identification of the elided argument in conjoined and purpose 
clauses. Pesh always shows an S/A pivot. In other words, Pesh has a nominative-accusative syntactic alignment in the two varieties.

\subsection{Conjoined clauses}

A significant characteristic for understanding syntactic alignment is behavior under crossclausal coreference, in particular the possibility of eliding the S/A in the second clause of two conjoined clauses which have coreferential subjects (Dixon 1994; Haig 1998). This construction is generally distinguished from reduction in purpose clauses (Dixon 1994, see Section 7.2), but in Pesh the behavior of the arguments in both constructions is the same. Conjoined clauses and purpose clauses lack an S/A argument that must be interpreted as coreferencial with the S/A of the first clause in the case of conjoined clauses and of the matrix clause in the context of purpose clauses. These constructions show an S/A pivot.

In Pesh, cross-clausal coreferential deletion shows interclausal control properties of the $\mathrm{S}$ or the A. The deletion in the conjoined clause operates on the basis of a nominative-accusative pattern. The two clauses are juxtaposed, and there is no connector between them. In (71), in the first clause the transitive verb $\mathrm{ka}$ 'make' has two arguments expressed in a nominal phrase, the A arwã 'the man' and the $\mathrm{O} y e$ 'the boy'.

Carbón

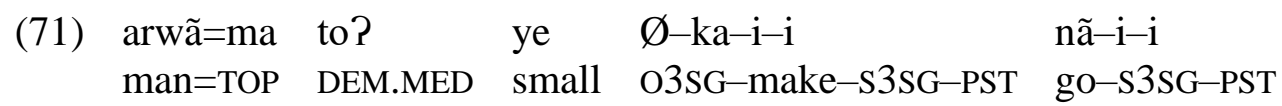

'The $\operatorname{man}_{\mathrm{i}}$ hit this boyk and $\varnothing_{\mathrm{i}}$ left.' $\quad\{\mathrm{txt}\}$

In (71), in the juxtaposed clause, the intransitive verb $n \tilde{a}$ ' go' occurs without a nominal phrase. The only possible referent of the missing $\mathrm{S}$ of the juxtaposed clause is the A of the first clause, that is, arwã 'the man'. In (72), in both clauses, the verbs are transitive: $p a$ 'take' in the first clause and $s a$ 'leave' in the second clause.

Culmi

(72)

$\begin{array}{llllll}\tilde{a} & \text { aso } & \text { a-wa=yã } & \text { manih=ya } & \text { to? } & \text { u?=ra } \\ \text { DEM.DIST } & \text { water } & \text { POSS3sG-eye=LOC } & \text { rabbit=ERG } & \text { DEM.MED } & \text { tiger=ACC }\end{array}$

$$
\begin{array}{ll}
\varnothing-\mathrm{pa}-\mathrm{k}-\varnothing-\mathrm{i} & \varnothing-\mathrm{sa}-\mathrm{k}-\varnothing-\mathrm{i} \\
\text { O3SG-take-K-S3SG-PST } & \text { O3sG-leave-K-S3SG-PST }
\end{array}
$$

'The rabbit ${ }_{\mathrm{i}}$ took the tiger $_{\mathrm{k}}$ to the bank of the river and $\varnothing_{\mathrm{i}}$ left himk.' $\quad\{\mathrm{txt}\}$

The two arguments are expressed in the first clause in nominal phrases: the A manih 'the rabbit' and the $\mathrm{O} u$ ? 'the tiger'. The collaborators claimed that the only possible referent of the missing $\mathrm{A}$ in the second clause is the $\mathrm{A}$ in the first clause, manih 'the rabbit'. This is more obvious when the number of the two arguments is different. In (73), the A arwa 'the man' is in the singular and the $\mathrm{O}$ in the plural. 
Culmi

(73)

$\begin{array}{llllll}\text { to? } & \text { arwã } & \text { korta } & \text { ka-ka-i-i } & \text { warki } & \text { ka-yẽh- } \varnothing-\mathrm{i} \\ \text { DEM.MED } & \text { man } & \text { woman } & \text { O3PL-make-S3SG-PST } & \text { bad } & \text { O3PL-say-S3SG-PST }\end{array}$

'This $\operatorname{man}_{\mathrm{i}}$ hit the women $_{\mathrm{k}}$ and $\emptyset_{\mathrm{i}}$ insulted them.'

The $\mathrm{S}$ or the A in the first clause may be marked by the topic marker, as in (71), by the ergative marker, as in (72) or unmarked, as in (73), but the strategy remains the same. The referent of the elided S, as in (71), and of the A, as in (72) and (73), in the second clause is always the A in the first clause.

Coreference between the $\mathrm{O}$ of the first clause and the A or the $\mathrm{S}$ of the second clause is possible but very unusual. In this context, the noun phrase that refers to the $\mathrm{O}$ of the first clause has to be repeated as an $\mathrm{S}$ in the juxtaposed clause as shown by to? ye 'this boy' in (74)

Carbón

(74)

arwã=ma to? ye $\varnothing-k a-i-i \quad$ to $\quad$ ye nã-i-i

man=TOP DEM.MED small O3SG-make-S3SG-PST DEM.MED small go-S3SG-PST

'The $\operatorname{man}_{\mathrm{i}}$ hit this boyk and this boyk left.'

In the same way, for coreference between the $\mathrm{O}$ of the first clause and the $\mathrm{A}$ of the second clause, the noun phrase that is the $\mathrm{O}$ in the first clause has to be introduced in the second clause, as an $\mathrm{A}$, as shown in (75) with $a$-arki 'his brother'.

Culmi

(75)

\begin{tabular}{|c|c|c|c|}
\hline to? & $\mathrm{ye}=\mathrm{ma}$ & $\mathrm{a}-\mathrm{arki}=\mathrm{ra}$ & $\begin{array}{l}\emptyset-\mathrm{ka}-\mathrm{i}-\mathrm{i} \\
03 \mathrm{sG}-\mathrm{mak}-\mathrm{s} 3 \mathrm{sG}-\mathrm{PST}\end{array}$ \\
\hline DEM.MED & small $=\mathrm{TOP}$ & POSS3SG - brother $=$ ACC & O3SG-make-S3SG-PST \\
\hline $\mathrm{a}-$ arki & $\varnothing$ & akkre- $\varnothing-\mathrm{i}$ & \\
\hline POSS3SC & brother & G-bite-S3SG-PST & \\
\hline
\end{tabular}

The $\mathrm{O}$ of the first clause needs to be repeated in the second clause whether it functions as an $\mathrm{S}$, as shown in (74), or an A, as illustrated in (75), in the second clause. The deletion of the S/A in the second clause when two clauses are conjoined shows that the target of this syntactic operation is always S/A. In other words, the syntactic alignment is nominative-accusative.

\subsection{Purpose clauses}

Reduction in purpose constructions shows what part of the argument of the matrix clause controls the elided element. This evidence for syntactic alignment has been shown to have the same alignment as that of the relative clause (Dixon 1994:102). This is the case in Pesh where the alignment in the purpose clause shows a nominative-accusative pattern.

In Pesh, purpose clauses are finite clauses that have restrictions: they are obligatorily marked by the future tense and the marker =ra (or =ro in Carbón), which functions as the purpose marker. This clause is postposed to the matrix clause, as shown in (76). 
Culmi

(76)

$\begin{array}{lll}\text { kakire } & \mathrm{i} \int \mathrm{ta}-\mathrm{k}-\varnothing-\mathrm{i} & \text { ta-wãwãh } \\ \text { midnight } & \text { get.up-K-S3SG-PST } & \text { POSS1-grandfather }\end{array}$

[ye korta=ra $\left.\varnothing-\mathrm{t} \int \tilde{\mathrm{e}}-\varnothing-\mathrm{pi}=\mathrm{ra}\right]$

small woman $=$ ACC $\quad$ O3SG-see-S3SG-FUT=PURP

'At midnight, my grandfatheri got up to $\emptyset_{\mathrm{i}}$ see the girl $\mathrm{k}_{\mathrm{k}} . \quad\{\mathrm{txt}\}$

In (76), the $\mathrm{S} t a-w \tilde{a} w \tilde{a} h$ 'my grandfather' in the matrix clause controls the reference in the purpose clause, functioning as the $\mathrm{A}$ of the verb $t \tilde{e}$ ' $s e e$ '. The $\mathrm{O}$ in the purpose clause takes the accusative marker. The presence of this marker is expected in this context, as this argument is the only one to be overtly expressed by an NP in this clause.

In example (77a), the verb in the matrix clause is a transitive verb pẽh 'ask' and the verb in the purpose clause is an intransitive verb te? 'come'.

Culmi

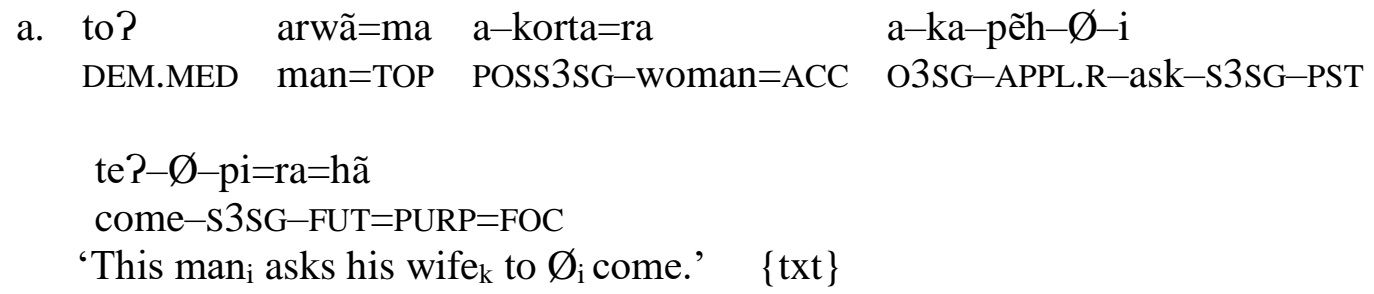

In example (77a), the A arwã 'man' and the O, the addressee korta 'the woman', are expressed in the first clause. In Culmi, which has a tripartite alignment and no marker for the S, the only possible reading is that the referent of the unmarked $\mathrm{S}$ in the purpose clause is the same as the $\mathrm{A}$ of the first clause, that is, arwã 'man'.

This raises the question about the way this construction may be understood in the Carbón variety. This variety has ergative-absolutive alignment and the absolutive marker $=$ ro may be used with the S. Sentences (77b) and (77c), which show a change in the position of $a$-korta=ro after the verb of the matrix clause, were proposed to my collaborators in Carbón and judged to be ungrammatical.

Culmi

(77) b. to? arwã=ma a-korta=ro a-ka-pẽh- $\varnothing-\mathrm{i}$ te?- $\varnothing-\mathrm{pi}=\mathrm{ra}=\mathrm{hã}$

*'This $\operatorname{man}_{\mathrm{i}}$ asks his wife $\mathrm{k}_{\mathrm{k}}$ to $\emptyset_{\mathrm{k}}$ come.'

'This $\operatorname{man}_{\mathrm{i}}$ asks his wife $\mathrm{k}_{\mathrm{k}}$ to $\emptyset_{\mathrm{i}}$ come.'

Carbón

(77) c. to? arwã =ma a-ka-pẽh- $\varnothing-\mathrm{i}$ a-korta=ro te?- $\varnothing-$ pi=ra=hã

*'This $\operatorname{man}_{\mathrm{i}}$ asks his wife $\mathrm{k}_{\mathrm{k}}$ to $\emptyset_{\mathrm{k}}$ come.'

'This $\operatorname{man}_{\mathrm{i}}$ asks his wife $\mathrm{k}_{\mathrm{k}}$ to $\varnothing_{\mathrm{i}}$ come.'

In Carbón, at the grammatical level it would be possible for $a$-korta=ro 'his wife' to function as the $\mathrm{S}$ of the verb in the purpose clause. However, for all the collaborators in Carbón, the sole possible interpretation for (77b) and (77c) is the same as in Culmi, that is, that $a-k o r t a=r o$ 'his 
wife' is the $\mathrm{O}$ in the matrix clause and cannot be the $\mathrm{S}$ of the verb te? 'come' in the purpose clause.

If we want to indicate that $a$-korta 'the wife', that is, the $\mathrm{O}$ in the matrix clause in (77), controls the $S$ in the purpose clause, the entire construction has to be modified, as in (78).

Carbón

$\begin{array}{llll}\text { to? } & \text { korta } & \text { a-arwã=ro } & \text { a-ka-pẽh- } \varnothing-\mathrm{i} \\ \text { DEM.MED } & \text { woman } & \text { POSS3SG-man=ABS } & \text { O3SG-APPL.R-ask-S3SG-PST }\end{array}$

[te?- $\varnothing-$ pi $=$ ro=hã]

come-S3SG-FUT=PURP=FOC

'This woman $_{\mathrm{i}}$ asks her husband $\mathrm{k}$ to $\emptyset_{\mathrm{i}}$ come.' $^{\circ}$

As in (78), the NP korta 'wife' must function as the A of the matrix clause to control the reference in the purpose clause. The $\mathrm{S}$ cannot be expressed by a NP in the purpose clause.

In (79), the verb in the matrix clause teP- $\emptyset$-t $\tilde{a}$ ' come to see' and the verb in the purpose clause Pif 'tell' are transitive.

\section{Carbón}

$$
\begin{aligned}
& \text { to? } \quad \text { arwã }=\text { ma } \quad \mathrm{a}-\mathrm{kawa}=\mathrm{ro} \quad \text { te?- }-\varnothing-\mathrm{t} \tilde{\mathrm{a}}-\varnothing-\mathrm{i}=\mathrm{na} \\
& \text { DEM.MED } \operatorname{man}=\mathrm{TOP} \text { POSS3SG-} \text {-spouse }=\mathrm{ABS} \quad \text { come }-\mathrm{O} 3 \mathrm{SG}-\mathrm{see}-\mathrm{S} 3 \mathrm{SG}-\mathrm{PST}=\mathrm{REP} \\
& \text { [a-Pi }-\varnothing-\text { pi=ro] } \\
& \text { O3SG-tell-S3SG-FUT=PURP }
\end{aligned}
$$

'They said that this $\operatorname{man}_{\mathrm{i}}$ came to see his spouse $_{\mathrm{k}}$ to $\emptyset_{\mathrm{i}}$ advise her ${ }_{\mathrm{k} .}$ ' $\{\mathrm{txt}\}$

The A arwã 'man' functions as the A in both clauses and the O, marked by the absolutive marker, is the $\mathrm{O}$ in both clauses; no ambiguity is possible.

In (80), I proposed to my collaborators a purpose clause with a change in reference, where the $\mathrm{O}$ in the matrix clause functions as the $\mathrm{A}$ in the purpose clause. All speakers considered example (80) to be ungrammatical.

\section{Carbón and Culmi}

$$
\begin{aligned}
& \text { (80) *to? } \\
& \text { DEM.MED man=TOP POSS3SG-spouse }=\mathrm{ABS} \quad \text { come }-\mathrm{O} 3 \mathrm{SG}-\text { see }-\mathrm{S} 3 \mathrm{SG}-\mathrm{PST}=\mathrm{REP} \\
& \text { [a-Pif- } \varnothing-\text { pi=ro] } \\
& \text { O3SG-tell-S3SG-FUT=PURP } \\
& \text { *'They said that this } \operatorname{man}_{\mathrm{i}} \text { came to see his } \text { spouse }_{\mathrm{k}} \text { to } \emptyset_{\mathrm{k}} \text { advise himi.' }
\end{aligned}
$$

The example in (80) is ungrammatical and my collaborators in Culmi and in Carbón proposed the sentence in (81) where no purpose clause is used but where two conjoined clauses are used instead (see Section 7.1). 
Carbón and Culmi
(81) to?
DEM.MED
arwã =ma $\quad \mathrm{a}-\mathrm{kawa}=\mathrm{ro}(\mathrm{ra})$
man=TOP
POSS3SG-spouse $=$ ABS
te?- $\varnothing-\mathrm{t} \int \tilde{\mathrm{a}}-\varnothing-\mathrm{i}=$ na
come-O3SG-See-S3SG-PST=REP
$\begin{array}{ll}\text { kawa } & \text { a-Pif- } \varnothing-\mathrm{i} \\ \text { spouse } & \text { O3SG-tell-S3SG-PST }\end{array}$
'They said that this $\operatorname{man}_{\mathrm{i}}$ came to see his spouse $_{\mathrm{k}}$ and the spouse $\mathrm{k}_{\mathrm{k}}$ advised himi.'

In the purpose clause, the reference is controlled by the $S$ or the A, showing an S/A pivot. The $\mathrm{S} / \mathrm{A}$ is omitted in the purpose clause, and in this clause the verb is obligatorily marked by the future and by the purpose marker $=r a(=r o)$. The purpose clause has a nominative-accusative pattern and an S/A pivot, just as it does in the conjoined construction.

\section{Conclusion}

Pesh shows a split ergative pattern at the morphological level and a nominative-accusative syntactic pattern. This situation is common in a number of morphologically ergative languages (Comrie 1978). Dixon (1994), among others, calls languages like Pesh "surface ergative."

The morphological characteristics specific to Pesh are cross-linguistically uncommon. The first typologically rare feature is the variable marking of both core arguments, the ergative and the absolutive or accusative. The second feature is an interesting split alignment governed by semantic features (verb-agreement affixes vs. free NP), grammatical properties (types of clause and variability of marking), and dialectal varieties. Pesh has a complex system of morphological alignment which is summarized in Table 3.

TABLE 3

TYPES OF MORPHOLOGICAL ALIGNMENT IN PESH

\begin{tabular}{llllllll}
\hline $\begin{array}{l}\text { Expression of } \\
\text { the arguments }\end{array}$ & Types of clause & $\mathrm{S}$ & $\mathrm{A}$ & $\mathrm{O}$ & $\begin{array}{l}\text { Type of } \\
\text { alignment }\end{array}$ & Marking & Variety \\
\hline $\begin{array}{l}\text { Verb-agreement } \\
\text { affixes }\end{array}$ & All & $\begin{array}{l}\text { Personal } \\
\text { suffixes }\end{array}$ & $\begin{array}{l}\text { Personal } \\
\text { suffixes }\end{array}$ & $\begin{array}{l}\text { Personal } \\
\text { prefixes }\end{array}$ & NOM-ACC & $\begin{array}{l}\text { Obliga- } \\
\text { tory }\end{array}$ & All \\
$\begin{array}{l}\text { Obligatory } \\
\text { marking }\end{array}$ & $\begin{array}{l}\text { Interrogative } \\
\text { content clause }\end{array}$ & $=r a /=r o$ & $=y a$ & $=r a /=r o$ & ERG-ABS & $\begin{array}{l}\text { Obliga- } \\
\text { tory }\end{array}$ & All \\
$\begin{array}{l}\text { Free NP marked } \\
\text { by a case } \\
\text { marker }\end{array}$ & $\begin{array}{l}\text { Independent / } \\
\text { matrix and } \\
\text { subordinate } \\
\text { clause }\end{array}$ & $=r o$ & $=y a$ & $=r o$ & $\begin{array}{l}\text { ERG-ABS } \\
\text { Tripartite }\end{array}$ & $\begin{array}{l}\text { Variable } \\
\text { Variable }\end{array}$ & CAR \\
& $\begin{array}{l}\text { Relative } \\
\text { clause }\end{array}$ & $=m a$ & $=m a$ & $=r a /=r o$ & NOM-ACC & Obliga & All \\
$\begin{array}{l}\text { Obligatory } \\
\text { marking }\end{array}$ & & & & & & -tory & \\
\hline
\end{tabular}


On the one hand, the alignment shows a split between the arguments expressed as verbagreement affixes (indexing) and the use of case markers on free NPs (flagging) and in interrogative and relative clauses. The indexing forms follow the nominative-accusative pattern, whereas the flagging forms reveal various types of alignment pattern: ergative-absolutive, tripartite, and nominative-accusative. This type of construction can be explained semantically by the nominal hierarchy (Silverstein 1976, DeLancey 1981, and Dixon 1994) where the NPs as free forms are mostly marked by the ergative-absolutive system and the person markers by the nominative-accusative system. On the other hand, three types of alignment pattern are conditioned by the type of clause and the dialectal variety. The obligatory marking in interrogative content clauses shows an ergative-absolutive alignment pattern in all the varieties. In independent and dependent clauses, the marking is variable and two types of alignment appear, conditioned by dialect: ergative-absolutive in Carbón and tripartite in Culmi. The latter seems to be diachronically derived from the former (see Section 5.3). In relative clauses, the marking is mandatory and has a nominative-accusative alignment pattern, showing that the relativization of the subject is related to topicality. In contrast, Pesh shows consistency of the same syntactic nominative-accusative alignment in cross-clausal behaviors in conjoined clauses and in S/A control with purpose clauses.

This study of morphological and syntactic features clearly shows a split ergativity at different levels for morphological alignment and a nominative-accusative alignment for syntactic patterns. The identification of these patterns adds significant new data to our knowledge of Chibchan languages, particularly when we consider the scarcity of studies that exist for this family (see also Chamoreau 2019). Some of the languages, such as Buglere and Costa Rican Guaymi, have nominative-accusative alignment, and perhaps Rama, Bokota and Kuna (although the available descriptions are unclear). Teribe also has nominative-accusative alignment as well as an inverse morpheme. According to Quesada (1999:23) eight Chibchan languages have ergative features: Maleku, Cabecar, Bribri, Guaymi, Tunebo, Ika, Damana, and Kogi. Pesh must be added to this list. Pesh is similar to Kogi in possessing a nominative-accusative system in its cross-reference marking and an ergative system in case marking. Quesada (1999) describes three types of ergative marking. The first is "Mayan style ergativity" in Maleku, which is the sole Chibchan language that has an antipassive marker. The second type is "discourse-run ergativity" in Cabecar and Bribri, in which ergative marking depends on information structure, in particular topic continuity. Ika (Frank 1990; Bajorat 2014) and Pesh (Chamoreau 2017, 2018) both fit into this group, in particular with respect to the focalization of a constituent by case marking. The third type, "intra-clausal ergativity", found in Guaymi, Ika, Kogi, Damana, and Tunebo, shows some split ergativity, in particular between the arguments expressed as verb-agreement affixes and the use of case markers on free NPs, such as Kogi. The features described for Pesh show that this language shares with Ika and Kogi (Magdalenian branch of Chibchan family, spoken in Colombia) some specific morphological traits and syntactic behavior (see also Chamoreau 2019).

Studies of syntactic alignment in Chibchan languages are almost non-existent. As Quesada (2007:86) has shown, nominative-accusative syntactic alignment predominates in Chibchan languages, with the possible exception of Maleku. Nevertheless, Constenla's description of Maleku (1998:193-197) does not allow definite conclusions to be drawn about the type of syntactic alignment in this language.

This study of Pesh, contrasting morphological and syntactic alignments, reveals a new and unknown pattern in the Chibchan family, which positions this language as a morphologically 
split ergative language. In Pesh, the split is due to intra-clausal and information structure features. However, Pesh also has less frequently reported features for split ergativity as dialects differ in terms of alignment. Differences between the two varieties reflect the diachronic evolution of alignment in each dialect.

\section{References}

Austin, Peter. 1981. Switch-Reference in Australia. Language 57 (2):309-334.

BAJORAT, JANA. 2014. Ergativity in Ika. Function and use of the marker -se'. MA dissertation, Humboldt-Universität zu Berlin.

Chamoreau Claudine. 2017. A preliminary grammatical sketch. Report. Major Documentation Project MDP0276, “A Cross-Varietal Documentation and Description of Pesh, a Chibchan Language of Honduras" (https:// elar.soas.ac.uk/ Collection/ MPI1050997). . 2018. Constituent order flexibility, differential case marking, and focus in Pesh. Paper presented at the workshop "OV basic word order correlates and information structure," Paris, 6-7 December, organized by the Institut National des Langues et Civilisations Orientales (INALCO), the Laboratory Structure et Dynamique des Langues (SeDyL), and the Laboratory of Excellence-Empirical Foundations of Linguistics (LABEX-EFL). 2019. Equative and similative constructions in Chibchan languages. Faits de LanguesJournal of Language Diversity 50 (1):157-174. . 2020a. Headless relative clauses in Pesh. Headless relative clauses in Mesoamerican Languages, eds. Ivano Caponigro, Harold Terrence, and Roberto Zavala, pp. 509-546. Oxford: Oxford University Press. . 2020b. Overt topic marking and discourse coherence in Pesh: Between correlation and divergence. Anthropological Linguistics. 61(2):1-30. . Forthcoming. Restrictive headed relative constructions in Pesh. A predominantly internally-headed relative clause language. Relative Clauses in Mesoamerican Languages, eds. Enrique Palancar, Roberto Zavala Maldonado, and Claudine Chamoreau. Amsterdam: Brill.

ComrIE, Bernard. 1978. Ergativity. Syntactic Typology: Studies in the Phenomenology of Language, ed. Winfred Lehmann, pp. 329-394. Austin: University of Texas Press.

Constenla UmaÑA, AdOLFO. 1998. Gramática de la lengua Guatusa. Heredia: Editorial de la Universidad Nacional.

. 2012. The Chibchan languages. The indigenous languages of South America: A comprehensive guide, vol. 2, eds. Lyle Campbell, and Verónica Grondona, pp. 391-437. Berlin: Mouton de Gruyter.

ConZemius, E. 1928. Los Indios Paya de Honduras. Estudio geográfico, histórico, etnográfico, y lingüístico. Journal de la Société des Américanistes 20:253-360.

De Hoop, Helen, AND ANDrej L. MAlChuKov. 2007. On fluid differential case marking: A bidirectional OT approach. Lingua 117:1636-1656.

DELANCEY, SCOTT, 1981. An interpretation of split ergativity and related patterns. Language 57:557-626.

DiXON, R.M.W. 1979. Ergativity. Language 55 (1):59-138. 1994. Ergativity. Cambridge: Cambridge University Press.

FAUCONNIER, Stefanie, AND JEAN-Christophe VERSTRAETE. 2014. A and O as each other's mirror image? Linguistic Typology 18 (1):3-49. 
Frank, PAUL. 1990. Ika Syntax. Arlington: Summer Institute of Linguistics and The University of Texas at Arlington.

HAIG, GEOFFREY. 1998. On the interaction of morphological and syntactic ergativity: lessons from Kurdish. Lingua 105:149-173.

Holt, DenNis. 1999. Pech (Paya). Munich: Lincom Europa.

LAMBRECHT, KNUD. 1994. Information structure and Sentence Form. Topic, Focus, and the Mental Representations of Discourse Referents. Cambridge: Cambridge University Press.

MCGREGOR, William B., AND JEAN-Christophe VERSTRAETE. 2010. Optional ergative marking and its implications for linguistic theory. Lingua 120:1607-1609.

MALCHUKOV ANDREJ L. 2017. Ergativity and differential case marking. The Oxford Handbook of Ergativity, eds. Jessica Coon, Diane Massam, and Lisa Demena Travis, pp. 253-279. Oxford: Oxford University Press.

QueSADA, JuAn DiEGO. 1999. Ergativity in Chibchan. Sprachtypologie und Universalienforschung 52 (1):22-51.

2007. The Chibchan languages. San José: Editorial Tecnológica de Costa Rica. 2012. Gramática del buglere. Quito: Abya Yala.

QUIZAR, STEPHANIE. 1979. Comparative word order in Mayan. PhD dissertation, University of Colorado, Boulder.

SCHULTZE-BERNDT, EVA. 2017. Interaction of ergativity and information structure in Jaminjung (Australia). The Oxford Handbook of Ergativity, eds. Jessica Coon, Diane Massam, and Lisa Demena Travis, pp. 1089-1113. Oxford: Oxford University Press.

Schulze, WolfGang. 2009. Grammar. The Caucasian Albanian Palimpsests of Mount Sinai, eds. Jost Gippert, Wolfgang Schulze, Zaza Aleksidze, and Jean-Pierre Mahe (vol. I), pp. 2160. Turnhout: Brepols.

SHIBATANI, MASAYOSHI. 1991. Grammaticalization of topic into subject. Approaches to Grammaticalization (Vol. II). Focus on Types of Grammatical Marker, eds. Elizabeth Closs Traugott, and Bernd Heine, pp. 93-133. Amsterdam: John Benjamins.

SilversteIn, MichAEL. 1976. Hierarchy of features and ergativity. Grammatical categories in Australian languages, ed. R. M. W. Dixon, pp. 112-171. Canberra: Australian Institute of Aboriginal Studies. 